\title{
Impressed Ware blade production of Northern Dalmatia (Eastern Adriatic, Croatia) in the context of Neolithisation
}

\author{
Sonja Kačar \\ Laboratoire TRACES UMR 5608, Université de Toulouse 2 - Jean Jaurès, Toulouse, FR \\ sonja.kacar@gmail.com
}

\begin{abstract}
The lithic assemblages from the principal early Neolithic sites in Northern Dalmatia have been analysed with respect to the technological aspects and principles of schéma and chaîne opératoire, débitage economy and raw material economy. Northern Dalmatia, the most fertile region of the Eastern Adriatic, hosts the most important Neolithic open-air sites. Early Neolithic is associated with the Impressed Ware culture and dates back to c. 6000-5400 cal BC. The Early Neolithic lithic assemblages are characterized by the pressure blade production techniques on high-quality Gargano cherts reflecting important socio-economic and technical mutations that are specific to the Neolithic. Moreover, the almost exclusive reliance on these exogenous cherts emphasizes the social aspects of such networks and reinforces the idea of cultural uniformity of Dalmatian and Apulian Impressed Ware.
\end{abstract}

KEY WORDS - lithic technology; Neolithisation; Dalmatia; Adriatic; Impressed ware; pressure flaking; Castelnovian

\section{Izdelava klin tipa Impresso v severni Dalmaciji (Vzhodni Jadran, Hrvaška) $v$ kontekstu neolitizacije}

\begin{abstract}
IZVLEČEK - Analizirali smo zbire kamnitih orodij iz najpomembnejših zgodnje neolitskih najdišč v severni Dalmaciji, pri čemer smo upoštevali predvsem tehnološke aspekte in principa schéma in chaîne opératoire, ekonomijo kamnitega odpada in ekonomijo surovin. Najpomembnejša neolitska najdišča na prostem so locirana $v$ Severni Dalmaciji, ki je najbolj rodovitna regija na Vzhodnem Jadranu. Zgodnji neolitik tukaj povezujemo s kulturo Impresso, ki datira v čas ok. 6000 do 5400 pr. $n$. št. Zgodnje neolitski zbiri kamnitih orodij so vezani na tehnologijo izdelave klin izdelanih iz visoko kakovostnih rožencev, ki prihajajo iz polotoka Gargano v Italiji, kar odseva pomembne družbenoekonomske in tehnične spremembe, ki so specifične za obdobje neolitika. Poleg tega uporaba roženca, ki prihaja skoraj izključno iz drugih pokrajin, poudarja družbene vidike takšnih mrež in krepi idejo o kulturni enotnosti $v$ dalmatinski in apulski kulturi Imresso.
\end{abstract}

KLJUČNE BESEDE - tehnologija izdelave kamnitih orodij; neolitizacija; Dalmacija; Jadran; izdelki tipa Impresso; tehnika lomljenja pod pritiskom; kultura Castelnovian

\section{Introduction}

In the context of European Prehistory, studies of the lithic industries of the Early Neolithic period in Dalmatia have long been neglected or have been limit-

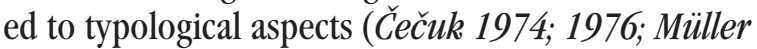
1994; Bass 1998). Regarding Northern Dalmatia, only one study, that from the open-air site Crno Vrilo, has been published in detail, but again mostly focusing on typological observations (Korona 2009). More detailed data is available from Southern Dalmatian cave sites, but the assemblages are small and/or from insecure contexts (Perhoč, Altherr 2011; FOrenbaher, Perhoč 2015; 2017; Šošić Klindžić et al. 2015). Recently, Zlatko Perhoč and Stašo Forenbaher opened new areas of research that consider the 
typo-technological aspects together with the raw material economy and modalities of distribution ( $\mathrm{FO}^{-}$ renbaher, Perhoč 2015; 2017).

However, synthesis work on the Early Neolithic assemblages combining both techno-typological aspects (concepts of schéma opératoire and chaîne opératoire) and the débitage economy with raw material economy is still lacking.

Lithic assemblages reflect the intentions of prehistoric knappers and the procedures they performed in their project realization, i.e. the choice of raw materials, methods and techniques employed, etc. While in some Mesolithic societies (i.e. the Early Mesolithic of the Balkans) their conceptual and operative schemes often depend on techno-environmental factors, with the Neolithic the socio-cultural aspects of lithic productions are emphasized ( $c f$. Inizan et al. 1999; Perlès 2009).

Therefore, the study of the Early Neolithic chipped stone assemblages not only informs us of the technoeconomical needs of the first farmers, but illustrates their social and ideological choices and relations. The strategies of the lithic production can reveal the contacts and interactions between the groups and their social and symbolic conceptions, but can also represent the routes and mechanisms of Neolithisation (Perlès 2009; Forenbaher, Perhoč 2017).

Moreover, in the context of Neolithisation, the study of chipped stone industries is essential to our understanding of the Mesolithic/Neolithic transition. In contrast to pottery, lithic production is an industry that the last hunter-gatherers and first farmers have in common. It consequently appears the most suitable production to evidence plausible generic links between those two types of societies. Did the first farming communities use the same methods and techniques in their lithic production as the last hunter-gatherers? Do the general schémas opératoires differ from Neolithic to Mesolithic sites? Are there notable differences in strategies of raw material procurement from a diachronical perspective?

In the literature dealing with the Mesolithic/Neolithic transition in the Eastern Adriatic, chipped stone industries have served either as evidence of cultural continuity (J. K. Kozłowski 1982; S. Kozłowski 2009; Marijanović 2007; 2009; Korona 2009) or for cultural rupture (Müller 1994). Typology was the only basis for such claims, while the hypothesis for 'continuity' was mostly founded on Montenegrin cave assemblages (Crvena Stijena, Odmut) (Benac 1955; Marković 1985; J. K. Kozłowski 1982; S. Kozłowski 2009; Marijanovic 2009). Obviously, however, the uncertain stratigraphic contexts of the Montenegrin assemblages cannot be used as one reference database for the whole Eastern Adriatic.

In general, lithic assemblages from Dalmatia reflect the complex strategies of lithic production as seen in the complex economy of raw material and a certain degree of techno-economic specialisation (Forenbaher, Perhoč 2017; Mazzucco et al. 2018; Podrug et al. in press a; in press b; Kačar 2019). This paper aims to examine the strategies of blade production

Fig. 1. Map of the main Dalmatian and Apulian impressed ware sites and the other sites mentioned in text. Framed: study area. Dotted lines: the hypothesized position of coastline during the $6^{\text {th }}$ millennium BC (based on bathymetric charts and the presumption that the sea level was -10 to $-15 \mathrm{~m}$ lower than today (cf. Surić 2006; Fontana et al. 2014). Dots: open-air sites, stars: caves. 1 Pokrovnik, 2 Ze munica, 3 Vela spila, $4 \mathrm{Na}$ kovana, 5 Gudnja, 6 Crvena Stijena, 7 Coppa Nevigata, 8 Rippa Tetta, 9 Masseria Giufredda, 10 Rendi-

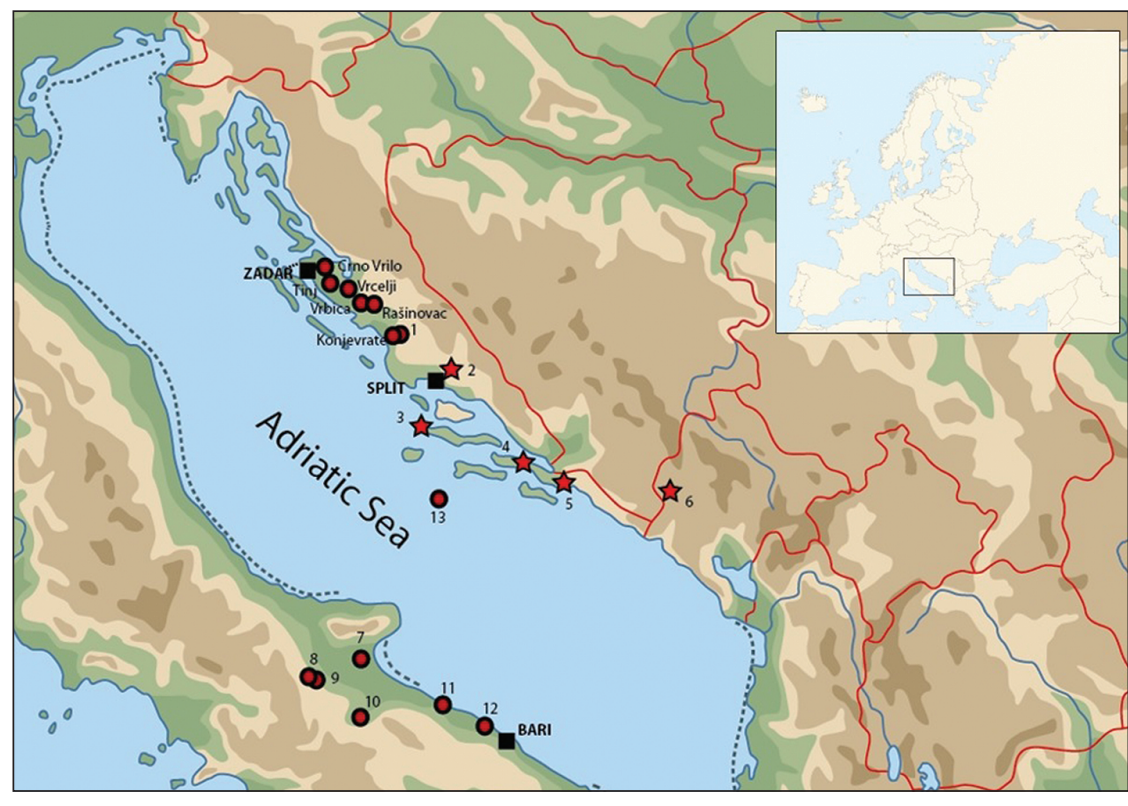
na, 11 Pulo di Molfetta, 12 Scamuso, 13 Sušac (background map designed by F. Tessier). 
in order to investigate its techno-economic and social aspects. As such it attempts to shed some new light on Neolithisation in the region.

\section{Materials and methods}

This study is based on Neolithic lithic assemblages from some main Impressed-ware sites in the Šibenik and Zadar regions (Northern Dalmatia): Rašinovac, Vrbica, Konjevrate, Crno Vrilo, Tinj and Polje Niže Vrcelja (Fig. 1). All the sites are open-air settlements, but the degree of research differs among them, as well as excavation strategies and methods employed. Konjevrate, Vrbica and Polje Niže Vrcelja were part of rescue excavations where large surfaces were open: c. $487 \mathrm{~m}^{2}$ in Polje Niže Vrcelja, $c .160 \mathrm{~m}^{2}$ in Konjevrate and c. 50 $\mathrm{m}^{2}$ in Vrbica (Brusić 1995; Menđušić 1998; Podrug 2013; Horvat 2015). Systematic excavations were carried on Crno Vrilo, where a total of $550 \mathrm{~m}^{2}$ excavated area has yielded the remains of a Neolithic village with rectangular houses (Marijanović 2009).

Trial excavations were conducted in Tinj and Rašinovac (Chapman et al. 1996; Podrug et al. in press a). In the latter only a small surface was open $\left(4 \mathrm{~m}^{2}\right)$.

Except Vrbica, which lacks the organic material, all the sites were radiocarbon dated (Tab. 1).

All ${ }^{14} \mathrm{C}$ dates mentioned in text have been recalibrated in 0xCal v4.3 (Bronk Ramsey 2009) and Int Cal13 (Reimer et al. 2013). However, some dates and namely those obtained for Tinj should be dismissed, as they show high standard deviation. Radiocarbon chronology ranges from the very beginning of $6^{\text {th }}$ millennium calBC to the $c .5400$ calBC. The earliest dates, around 6000/5900 cal BC, have been obtained from Rašinovac in Šibenik county. Crno Vrilo and Konjevrate can be placed roughly between 5800 and $5500 \mathrm{cal} \mathrm{BC}$. The youngest dates are obtained from Polje Niže Vrcelja, placing its occupation to the very end of the impressed-ware phase, $c$. 5500-5400 cal BC. Despite the lack of ${ }^{14} \mathrm{C}$ dates for the Vrbica assemblage, the presence of one bifacial retouched point, typical for the Danilo phase and Danilo-like sickle insert (Mazzucco et al. 2018), might suggest its affiliation with the later phase of Impressed ware culture.

Following this, it should be noted that the majority of Early Neolithic material studied in this work belongs to the later phase of Impressed ware (from $c$. $5800 \mathrm{cal} \mathrm{BC}$ ), while only one assemblage (Rašinovac) can be dated to the very beginning of the Neolithic in the Adriatic region (c. $6000 \mathrm{cal} \mathrm{BC}$ ) (Forenbaher et al. 2013; Forenbaher, Miracle 2014; McClure et al. 2014; Podrug et al. in press).

However, the Rašinovac assemblage doesn't show any significant difference from the technological and petrological points of view with other, younger assemblages. Moreover, according to available published data, as well as from the author's personal observations, the Early Neolithic assemblages of Southern Dalmatia, dated between $c .6000$ to $5500 \mathrm{cal} \mathrm{BC}$, are probably characterized by the same schéma opératoire, i.e. the same technology and raw material economy (Bass 1998; Marijanović 2005; Forenbaher, Kaiser 2008; Forenbaher, Perhoč 2015; 2017; Drnić et al. 2018; Mazzucco et al. 2018).

Thus, although this paper deals with the Early Neolithic lithic production of Northern Dalmatia, broader conclusions can be drawn that will concern the whole of Dalmatia.

The question of the origin of the Neolithic chert industries and its place within the discussion of Neolithisation is limited, since the Late Mesolithic sites are absent from the region. The only site in Dalmatia where Late Mesolithic occupation is clearly attested is Vela Spila on the island of Korčula, but the small quantities of collected lithic material do not allow any techno-typological and cultural attribution ( $\breve{C} e$ čuk, Radić 2005; Vukosavljević 2012). However, when discussing the relevance of lithic studies in the Neolithisation process, in order to compare the Impressed ware industries with the previous periods, we refer to the Castelnovian lithic production strategies of adjacent regions (Collina 2009; Binder et al. 2012; Ferrari 2011; Kačar 2019). The Castelnovian techno-complex developed during the 7 th millennium BC and characterizes the Late Mesolithic lithic assemblages of the central-western Mediterranean, but is absent from Croatia and Greece (Kozłowski 2009; Marchand, Perrin 2017). While its absence from Greece can be interpreted by the early presence of Neolithic colons in this region (from $c$. $6700 \mathrm{cal} \mathrm{BC}$ ), its absence from the Croatian littoral (both Dalmatia and Istria) is curious because analogous industries have been found in the neighbouring regions (Italian and Slovenian Karst, Po valley, Montenegro) (Biagi 2003; Turk 2000; Mihailović 2009; Kozłowski 2009; Ferrari 2011; Kaczanowska, Koztowski 2017; Kačar 2019). We therefore think that the absence of Castelnovian finds along the Croatian coast is due to a lack of research and preservation 


\begin{tabular}{|c|c|c|c|c|c|c|c|c|c|c|c|c|c|c|c|c|c|c|}
\hline 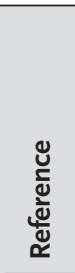 & 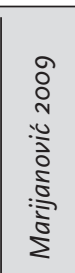 & 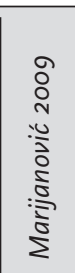 & 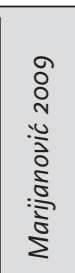 & 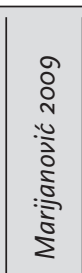 & 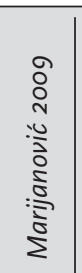 & 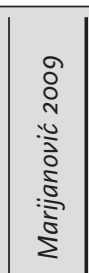 & 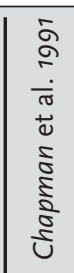 & 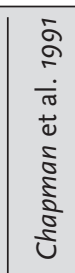 & 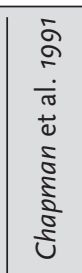 & $\begin{array}{l}n \\
\hat{D} \\
\stackrel{5}{0} \\
\overrightarrow{0} \\
\text { I }\end{array}$ & 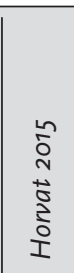 & 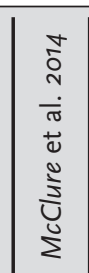 & 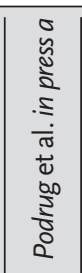 & 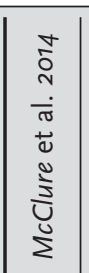 & 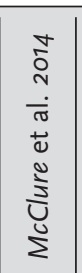 & 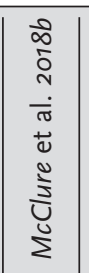 & 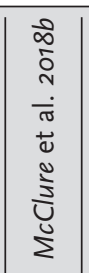 & 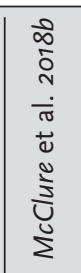 \\
\hline 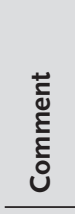 & 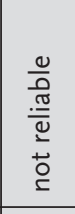 & 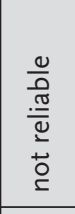 & 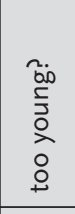 & & & 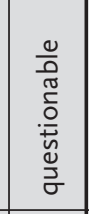 & 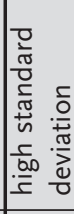 & 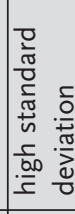 & 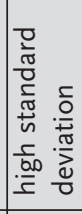 & & & & & & 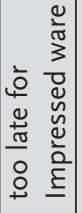 & & & \\
\hline 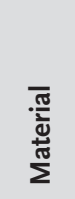 & 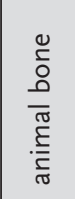 & 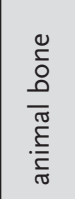 & 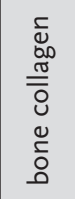 & 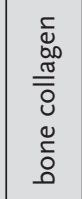 & 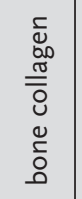 & 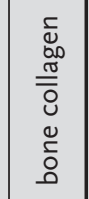 & & & & $\begin{array}{l}\overline{\frac{\pi}{0}} \\
\frac{\bar{\nu}}{\tilde{\pi}} \\
\frac{\pi}{U}\end{array}$ & 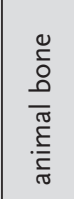 & 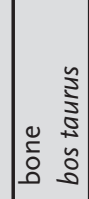 & 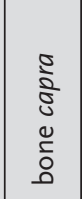 & 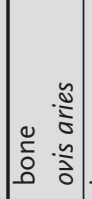 & 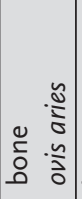 & 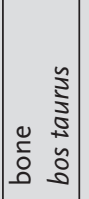 & 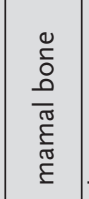 & 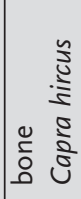 \\
\hline \multirow{2}{*}{ 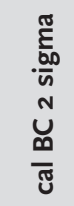 } & 仓ิ & 筩 & $\stackrel{\infty}{\tilde{n}}$ & స్త్రి & 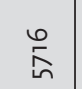 & $\overline{\tilde{n}}$ & $\stackrel{\sigma}{\circ}$ & $\begin{array}{l}0 \\
0 \\
0 \\
0\end{array}$ & 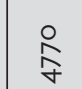 & 它 & $\overline{\tilde{\aleph}}$ & 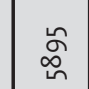 & $\begin{array}{l}\infty \\
\text { o } \\
\text { wn }\end{array}$ & 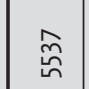 & 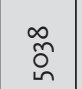 & $\stackrel{\infty}{\stackrel{\infty}{n}}$ & $\tilde{\tilde{n}}$ & $\begin{array}{l}0 \\
\stackrel{0}{\infty} \\
\infty\end{array}$ \\
\hline & है & 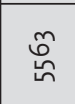 & $\stackrel{\bar{\sigma}}{\text { 呙 }}$ & 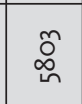 & $\underset{\substack{\infty \\
\sim \sim}}{\bar{n}}$ & $\begin{array}{l}\stackrel{\infty}{\infty} \\
\stackrel{\infty}{\sim}\end{array}$ & ్ㅗㄴ & $\begin{array}{l}\overline{0} \\
0 \\
0\end{array}$ & స్ & 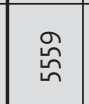 & 尺్ & $\overline{8}$ & $\begin{array}{l}+ \\
\stackrel{0}{0} \\
\stackrel{0}{0}\end{array}$ & 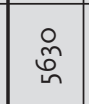 & $\stackrel{\infty}{\sim}$ & œ & 芩 & م. \\
\hline \multirow{2}{*}{ के } & $\stackrel{\text { ్ }}{\sim}$ & $\stackrel{\circ}{\rightleftharpoons}$ & 8 & 음 & o & $\stackrel{\sim}{m}$ & $\stackrel{\circ}{\circ}$ & @্ & $\stackrel{\circ}{N}$ & $\stackrel{\circ}{+}$ & 온 & $\stackrel{\sim}{\sim}$ & $\stackrel{\sim}{N}$ & $\stackrel{\llcorner}{\sim}$ & $\stackrel{\circ}{\text { r }}$ & i & นั & $\stackrel{\circ}{m}$ \\
\hline & $\stackrel{\circ}{\stackrel{\circ}{h}}$ & $\begin{array}{l}\stackrel{\circ}{0} \\
\text { ఫे }\end{array}$ & 。̊ & 今్ & ஃ & స్ & 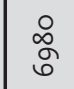 & \begin{tabular}{l}
$\circ$ \\
\multirow{\delta}{0}{}
\end{tabular} & @ & ్ㅗㅀ & 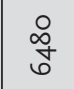 & $\begin{array}{l}\circ \\
\stackrel{2}{\circ}\end{array}$ & 怘 & 点 & $\stackrel{\kappa}{\stackrel{\sigma}{\sigma}}$ & 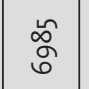 & 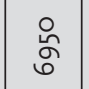 & ঃ \\
\hline 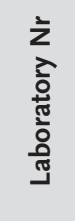 & $\begin{array}{l}\stackrel{\sigma}{\tilde{N}} \\
\stackrel{\sim}{N}\end{array}$ & $\stackrel{\infty}{\stackrel{\infty}{\tilde{N}}}$ & 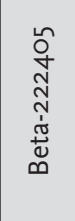 & 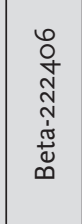 & 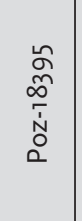 & 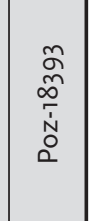 & 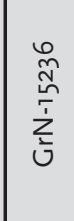 & 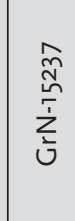 & 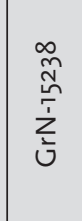 & $\begin{array}{l}0 \\
\infty \\
0 \\
N \\
N \\
\tilde{N} \\
\tilde{N} \\
\infty\end{array}$ & 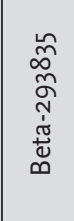 & 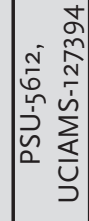 & 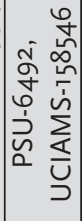 & 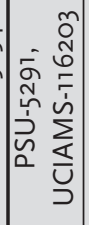 & 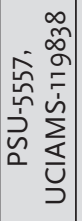 & 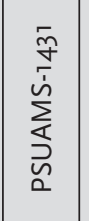 & 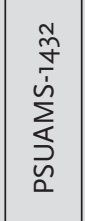 & 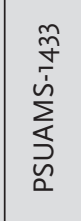 \\
\hline 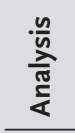 & y & y & $\sum_{<}^{n}$ & $\sum_{<}^{n}$ & $\sum_{<}^{n}$ & $\sum_{<}^{n}$ & y & y & 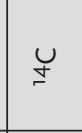 & y & U & $\sum_{<}^{n}$ & $\sum_{<}^{n}$ & $\sum_{<}^{n}$ & $\sum_{<}^{n}$ & $\sum_{<}^{n}$ & $\sum_{<}^{n}$ & $\sum_{<}^{n}$ \\
\hline 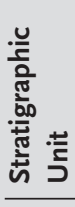 & 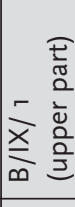 & & 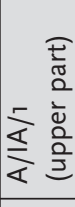 & 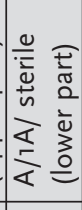 & 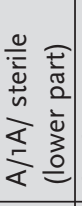 & 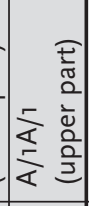 & 产 & 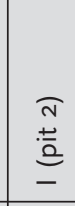 & $\begin{array}{l}\bar{m} \\
\frac{ \pm}{0} \\
-\end{array}$ & 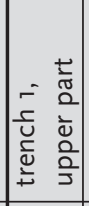 & 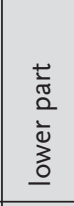 & 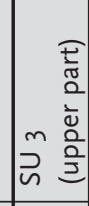 & 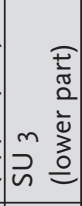 & 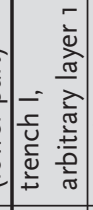 & 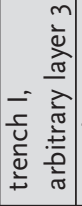 & 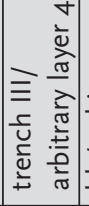 & 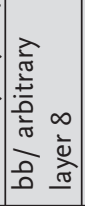 & 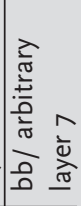 \\
\hline 홓 & 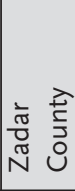 & & $\begin{array}{l}\frac{\pi}{0} \\
\frac{\pi}{0} \\
N \\
N\end{array}$ & 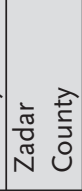 & 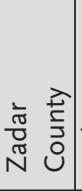 & 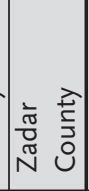 & 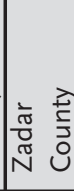 & $\begin{array}{ll}\frac{\pi}{\pi} \\
\frac{\pi}{5} \\
\text { N } \\
N\end{array}$ & \begin{tabular}{|l}
$\frac{\pi}{\pi}$ \\
$\frac{5}{3}$ \\
$N$ \\
$N$
\end{tabular} & $\left|\begin{array}{ll}\frac{\pi}{\pi} & \multicolumn{3}{c}{} \\
& 0\end{array}\right|$ & 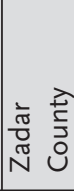 & 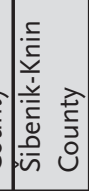 & 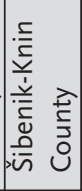 & 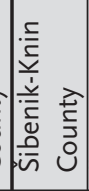 & 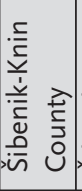 & 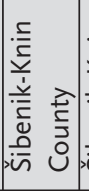 & 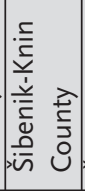 & 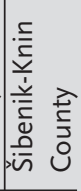 \\
\hline & 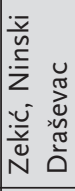 & 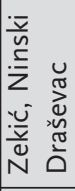 & 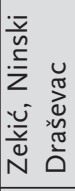 & 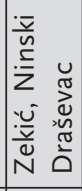 & 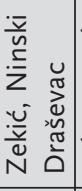 & 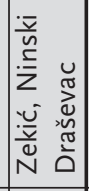 & 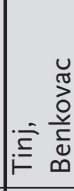 & 童 & 竞 & 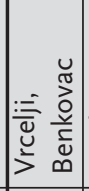 & 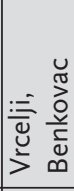 & 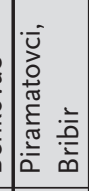 & 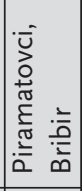 & 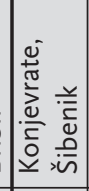 & 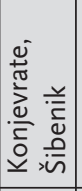 & 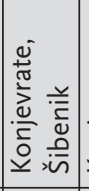 & 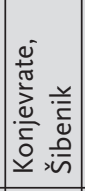 & 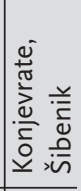 \\
\hline 音 & $\begin{array}{l}\stackrel{0}{\bar{\Sigma}} \\
\text { 足 } \\
\stackrel{0}{E}\end{array}$ & 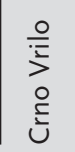 & 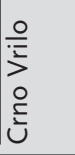 & 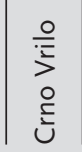 & 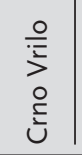 & 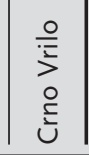 & $\overline{\underline{\underline{I}}}$ & $\bar{\Xi}$ & $\mid \bar{\Xi}$ & 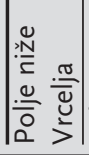 & 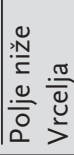 & 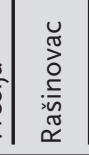 & 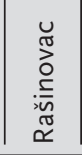 & 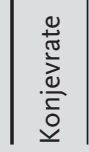 & 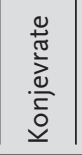 & 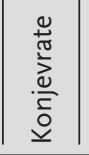 & 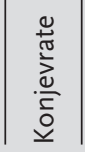 & 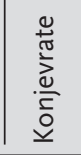 \\
\hline
\end{tabular}


factors (the sites could have been submerged due to the Holocene sea-level rise or buried under alluvial deposits).

Lithic analyses have been carried out according to the concepts of chaîne and schéma opératoire, débitage economy and raw material economy (LeroiGourhan 1965; Pelegrin 1988; Inizian 1980; Perlès 1980; 1990; 1991; Inizan et al. 1999; Soressi, Geneste 2011). When describing stone tools, the typology established by Didier Binder and further developed by Thomas Perrin is generally used, but in its simplified form (Binder 1987; Perrin et al. 2017). Although the raw material was examined macroscopically by the author according to the protocol established by Bressy in 2003, we are here largely relying on the published and unpublished work of Perhoč (Perhoč 2009ab; Perhoč, Altherr 2011; Forenbaher, Perhoč 2015; 2017; Vukosavljević et al. 2014; Vukosavljević, Perhoč 2017; Vujević et al. 2017; Perhoč, Ruka 2017). However, as his petrographic analysis on the assemblages mentioned in this article is still in progress, the results presented here should be considered preliminary. Our data will soon be correlated for a final publication, and here I take the opportunity to thank Perhoč for allowing me use some of his preliminary results.

\section{Northern Dalmatia - geographic framework and subsistence strategies}

Northern Dalmatia, as a central part of the Eastern Adriatic region, includes Zadar and Šibenik-Knin county, and spreads roughly from the southern edge of the Velebit mountain to the north to Krka River to the south. In the west, the region includes the Adriatic Sea and the Dalmatian islands (from Pag to Zlarin) and, on the east, it spreads to the Dinara mountains which constitute the natural border between Croatia and Bosnia. Unlike the Italian coastline, which is low and accessible, the Croatian coast is well indented and high (the Dinaric mountain range falls abruptly towards the coast, except for few narrow coastal plains). The relief of Northern Dalmatia is, compared to other parts of the region, less pronounced and characterized by the relative richness of the plains, in particular Ravni Kotari and poljes around Sibenik.

Almost all known Dalmatian open-air sites are situated here, on the fertile soils and always close to water sources (Fig. 2).

The region seems to have been rather densely populated during the Early Neolithic, with at least 20 open air-sites identified, the occupational sequence of 11 of which was confirmed by excavations (Horvat 2017; Podrug et al. in press a).

There is still one obvious lack of data to inventory the zooarchaeological and archeobotanical record of the Early Neolithic in Northern Dalmatia, although in the present state of research, analysis broadly shows that the economy of the early Neolithic population was dominated by ovicaprines for a combined milk-meat husbandry strategy, and that agriculture is based on emmer, einkorn and barley (Radovic 2011; Reed 2015; McClure et al. 2018a).

According to the faunal record, it seems that hunting and fishing played only a marginal role, although lithic kits might indicate this practice, notably with the presence of hunting equipment like trapeze arrowheads. However, trapeze arrowheads could have also been used in warfare or for some other purposes. The paucity of fishing equipment could be explained by the distance of the sites from the larger waterbodies, as well as by the perishability of the osseous material, but it can also reflect cultural choices. In this regard, it is worth mentioning the results from the stable isotope analyses conducted recently on Early Neolithic humans from Zemunica cave (near Split in Southern Dalmatia), which show that the diet of these individuals was completely terrestrial, consisting mainly of domesticated animals (Guiry et al. 2017).

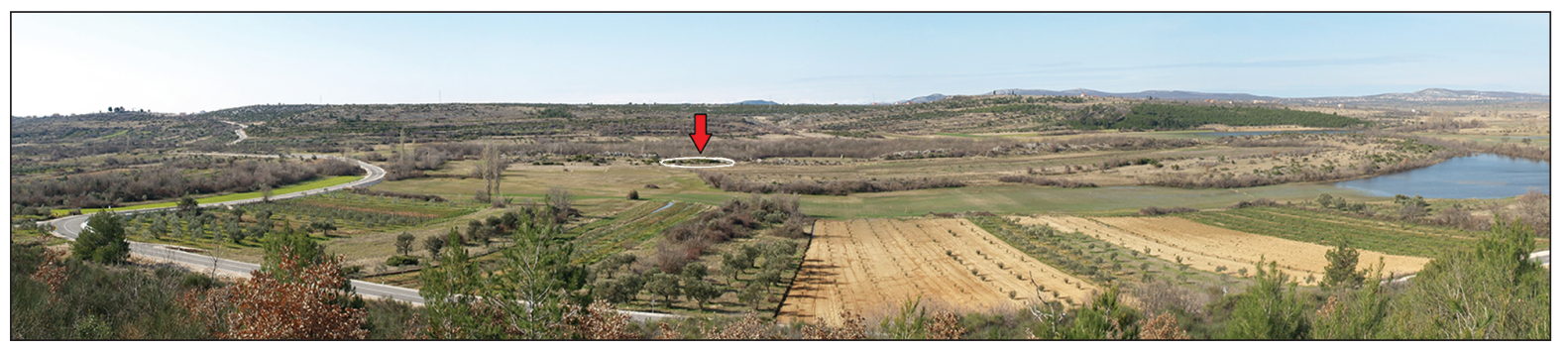

Fig. 2. Piramatovac valley viewed from the southeast with position of Vrbica site (encircled). Photo by Emil Podrug. 


\section{The Neolithisation of the Eastern Adriatic}

The Neolithisation of the Eastern Adriatic region begins at the onset of the $6^{\text {th }}$ millennium and it is associated with the Impressed ware culture. During period, the same culture, with some regional differences in ceramic production which evolved over time, spread on the Italian shore of the Adriatic.

The earliest Neolithic sites of Northern Dalmatia are dated from the beginning of $6^{\text {th }}$ millennium. They are thus contemporary with the oldest Neolithic occupations of the Eastern Adriatic. In the light of new radiocarbon dates, Stašo Forenbaher and Preston Miracle (2014) recently revisited their former model of Neolithisation (Forenbaher, Miracle 2005; 2006) arguing that some interactions between local foragers and newcomer farmers (whose presence seems only evidenced in caves) took place all over the Adriatic coast during the beginning of $6^{\text {th }}$ millennium and that the real colonization (settlement foundation) occurred about 150 year later (c. 5900-5800 cal $\mathrm{BC}$ ), moving progressively from the south to the north.

Recent field research conducted in Northern Dalmatia slightly modified this model. The early dates for open-air sites like Rašinovac and Pokrovnik appear to corroborate the simultaneity of cave and open-air settlements (Müller 1994; McClure et al. 2014), and challenge the proposed anteriority of cave sites over open-air sites (Batović 1979; Forenbaher, Miracle 2014; Forenbaher, Perhoč 2017.202). The distinction between cave and open-air sites is purely functional (McClure et al. 2014.1036), whereas only the latter can precisely reflect the Neolithic way of life (Guilaine 2005.60).

Still, the majority of the open-air sites do not belong to the earliest phase of the Neolithic occupation, but are dated a few centuries later, between 5800 to 5400 cal BC.

Moreover, Forenbaher and Miracle reopened the question of the possible west-east direction of colonization (from Apulia to Dalmatia), since the radiocarbon dates obtained for South Italian villages are somewhat older than the Dalmatian ones (Müller 1994.259; Forenbaher, Miracle 2014.238, Forenbaher, Perhoč 2015.66; 2017.202-204). However, as already mentioned, the new dates obtained from Pokrovnik and Rašinovac place the foundation of those villages at the beginning of $6^{\text {th }}$ millennium, which sets them as contemporaneous to the South
Italian sites. It must be noted that those 'early' dates from Apulia ( $c f$. Rendina, Masseria Giufreda and $\mathrm{Pu}$ lo di Molfetta), are problematic, as they show large standard deviations and/or are coming from insecure or later contexts (Guilaine et al. 2003.372; Radina 2007; Collina 2009.52,57; Guilbeau 2010.71). Moreover, all the recently obtained radiocarbon dates from the earliest Neolithic occupations of Apulia are still slightly younger then the Dalmatian ones (Binder et al. 2017).

Thus, if one relies on firm data, the reliable current radiocarbon dates suggest a temporal priority to the Eastern Adriatic open-air sites.

However, considering the latest discoveries in the strategies of raw material procurement, pointing to sources on the Gargano promontory, the possibility of Apulian influences in the Neolithisation process in Dalmatia should not be rejected (Forenbaher, Perhoč 2015; 2017; Podrug et al. in press a).

Nevertheless, while the richness of Neolithic sites confirms that that colonization played a major role in establishing a Neolithic way of life, evidence for the presence of last hunter-fisher-gatherers in the Eastern Adriatic is still pretty scarce. In the literature, the open-air site of Lokve is sometimes referred to as Castelnovian (Komšo 2007.66; Mihailovic 2009.103; Kaczanowska, Kozłowski 2017.203). However, the related material collected from unsecure contexts (see Komšo 2009.292) displays important heterogeneity in the both raw material economy and typo-technology (Kačar 2019).

As already mentioned, thus far, Castelnovian is absent from Dalmatia. Further research is needed in order to demonstrate whether this outlines an historical reality or if this situation is related to some other factors, such as, for example, some shift in the settlement pattern and/or loss of the sites by marine transgression, lack of research, and so on.

\section{Lithic production strategies in the Early Neoli- thic of South-eastern Europe and the Central Mediterranean}

'Prismatic blade technology' or 'long blade technology' is often considered to be a part of the so called 'Neolithic package', and thus one of the elements that transmits from the Near East to Europe.

Without going into further discussion about the concept of this 'package' and its content, one cannot but 
notice the sudden presence of long blades in Neolithic contexts all over South-eastern Europe.

In order to obtain blade blanks two main knapping techniques are generally used during the European Neolithic: indirect percussion and pressure flaking.

The technique of pressure flaking consists of applying great force on one precise point on the platform in order to obtain blades or bladelets. Indirect percussion involves the application of an intermediary tool, called a 'punch', which can be made of wood, antler or bone (Inizan et al. 1999.32).

The main advantage of pressure flaking and indirect percussion over direct percussion is greater productivity and profitability. They both allow a Prehistoric knapper to maximize their production since they will obtain a considerable number of blades from a single block.

The identification of the two techniques is possible due to experimental work by several archaeologists, like François Bordes, Don Crabtree, Jacques Texier, and Jacques Pelegrin. There are some general morphological criteria that individualized the two techniques (cf. Inizan et al. 1999; Pelegrin 2012). Thus, the pressure technique is identified by the regularity and standardization of blade products. This regularity is due to the immobilization of the core and the pressure force that is continuous and intense. Hence, a straight profile, parallel edges and ridges and a constant thickness characterize the blades. On the other hand, blades obtained by indirect percussion are in general larger, but less standardized and characterized by a curved profile. However, as archaeological and experimental examples show, blades obtained by indirect percussion can also be very regular, whereas the pressure flaked blades could show high variation in regularity. Besides, one must bear in mind that experimentation conducted with pressure flaking is much better documented than experimentation on indirect percussion.

Although the concept of pressure flaking was known since the Upper Palaeolithic, the two techniques were widely used in blade production since the Late Mesolithic (Binder, Perlès 1990; Inizan et al. 1999). Pressure flaking was widespread during the Late Mesolithic Castelnovian culture in the Mediterranean (Binder 1987; 2010). The closest Castelnovian industries to the region, those from Montenegro, are also characterized by pressure flaking (Kačar 2019). During the Neolithic, this technique is also common all over the Mediterranean (Binder 1987; 2007; 2010; Perlès 1990; 2001; Horejs et al. 2015) and at least in some parts of South-eastern Europe like Bosnia and Serbia (I. Jovanović pers. comm.).

The indirect percussion or 'punch' technique is present during the Late Mesolithic in Southern and Northern Europe (Allard 2007.219; Perrin 2009. 518; Ferrari 2011), but it seems marginal in the Castelnovian of Montenegro (Kačar 2019). During the Neolithic, it became the common technique for blade production in different regions of Europe. Indirect percussion is well attested in the Early Neolithic Starčevo-Körös culture (Mateiciucová 2007.701; Šošić-Klindžić, Karavanić 2004.26; Karavanić et al. 2010.15; pers. comm. J. Pelegrin and I. Jovanović, personal observations). In the Early Neolithic of Bulgaria (Karanovo I-II), it is a common technique for obtaining long blades (Gurova 2014). However, this technique was not exclusive for producing long and large blanks, since the Starčevo-Körös assemblages are characterized by bladelets (Mateiciucová 2007; Šošić-Klindžić, Karavanić 2004; Karavanić et al. 2010; personal observations). Large butts, sometimes concave, pronounced bulbs together with a certain irregularity of blanks, point rather to the use of indirect percussion.

As demonstrated above, the archaeological evidence shows that the use of so-called complex débitage techniques (pressure and indirect percussion) is not a Neolithic novelty, but appears from the Late Mesolithic. However, the almost systematic use of exogenous rocks in this production, as recorded in some parts of the South-eastern Europe, is an element specific to the Neolithic.

The exploitation of exogenous raw materials certainly began in the Mesolithic (or in the final Palaeolithic), as evidenced, for example, by the Melian obsidian which circulates in the Aegean, but unlike the Neolithic, the production on these exogenous rocks does not differ from that of local rocks, since they are both characterized by an simple technical investment (for an expedient production of flakes, see Perlès 1990; 1991; 2009).

In Central and Western Europe, so-called 'Carpathian' obsidian and Wommerssom quartzite also appear to circulate over a larger area before the Neolithic ( $\mathrm{Ma}$ teiciucová 2007; Kozłowski 2009).

Nevertheless, as claimed by Catherine Perlès (2009. 558), "[...] there is no economy of raw materials, 
in the sense of a differential exploitation". These exogenous rocks have therefore been exploited in the same way as the local raw material. Conversely, from the Neolithic, a more 'complex' raw material economy is implemented, and this change in the exploitation strategies of raw materials is linked to social or economic factors (Perlès 1990; 1991; 2009. 558-563).

From the very beginning of the Neolithic $(c .6700-$ 6000 cal BC), several raw material distribution networks were operating in the Central Mediterranean and the Balkans (Fig. 3).

Those networks differ according to the extension of the network concerned, i.e. according to the distribution area: some may be considered local and/or regional (for example the 'Marche' cherts or the Northern Bosnian rocks, 'chocolate flints' from Northern Greece, Mont Lessini cherts), and others interregional (obsidian from Melos and Lipari, Gargano cherts). Nevertheless, at this stage, the characterization of these networks is limited and requires more in-depth regional studies. Moreover, the size of the territory alone is not sufficient to distinguish a regional network from an inter-regional one, but other factors, such as geographical constraints, must be taken into account (for example, 'Carpathian' obsidian circulates over an territory of significant size, but geographically this is the relatively easily crossed Panno- nian Basin). In Figure 3 we have tried to trace these networks, which in our opinion can indicate not only the contacts between distinct geographical groups, but could also illustrate the routes and directions of Neolithization.

In some cases these exogenous rocks of regional/interregional origin ('Silex blond' from Greece, 'Balkan flint'/'white-spotted flint' in the Central Balkans and Gargano cherts in Southern Italy and Dalmatia) have been exploited in a different way than local cherts, indicating a complex form of techno-economic production (Perlès 1990; 2009; Collina 2009; Guilbeau 2010; Forenbaher, Perhoč 2015; Guilbeau, Perlès 2016; Gurova et al. 2016; Kačar 2019).

Gargano cherts - an important element of Southern Italian and Dalmatian Impressed Ware culture

Recent research has shown that artefacts made from Gargano cherts are recorded at many Early Neolithic sites of Southern Italy (namely from the Northern Apulian Tavoliere region, as well as from Northern Basilicata and Eastern Calabria) and Dalmatia, evidencing that those important source deposits have been used since the very beginning of the Neolithic, from c. 6000 cal BC (Collina 2009; 2015; Guilbeau 2011; 2012; Forenbaher, Perhoč 2015; 2017; Tarantini 2016; Mazzucco et al. 2018; Kačar 2019).

\section{Fig. 3. Illustration of known raw material di- stribution networks in the Central Mediterra- nean and the Balkans, during the Early/Middle Neolithic, between c. 6700 and 5000 cal BC (the displayed dates in- dicate the beginning of distribution in the Neo- lithic). Dotted lines: ma- ximum extension of the network in the Early Neo- lithic (light dotted lines with titles in bold repre- sent obsidian distribu- tion networks). A ques- tion mark (?) indicates the presence of high qua-} lity chert of unknown,

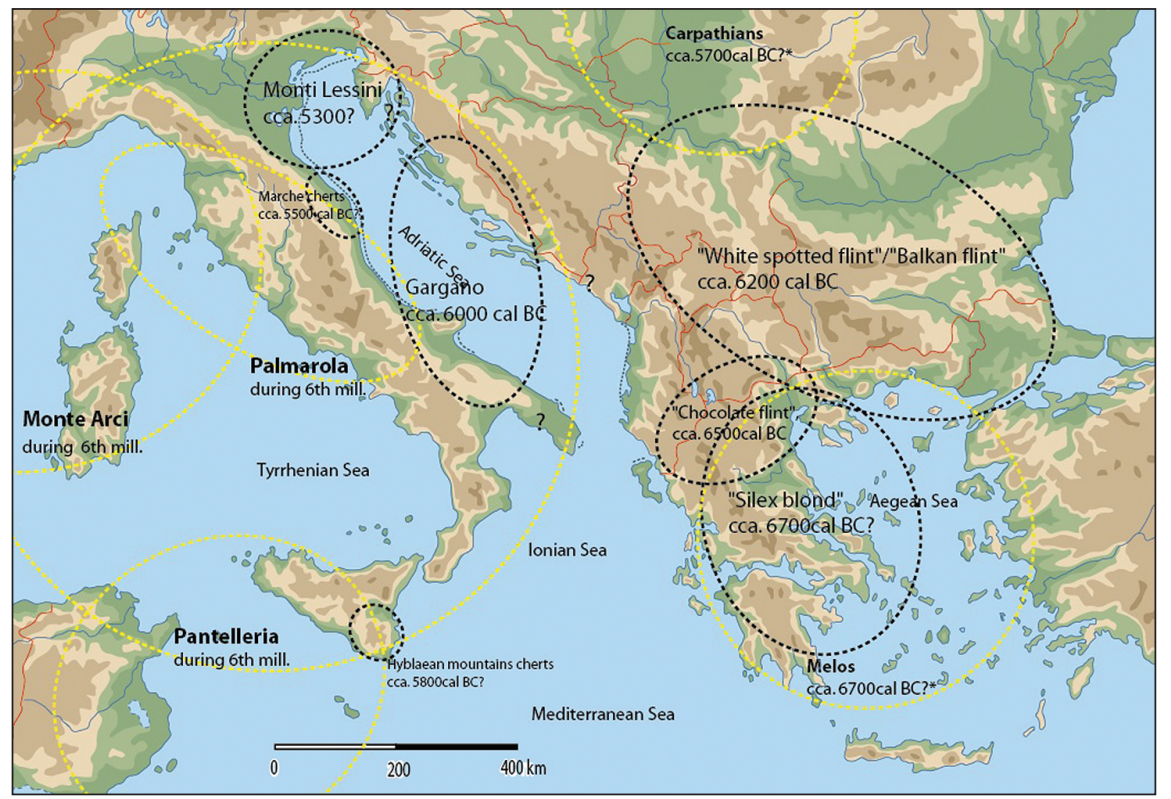
but probable exogenous origin. An asterisk (*) indicate the existence of pre-Neolithic networks (according to Perlès 1987; 1990; 2004; 2009; Komšo 2006; Mateiciucová 2007; Kaczanowska, Kozłowski 2008; Collina 2009; Guilbeau 2010, 2011; Guilbeau, Erdoğu 2011; Šošić-Klindžić 2011; Reingruber 2011; Gurova 2012,2014; Gurova et al. 2016; Conati Barbaro et al. 2014; Freund 2014; 2018; Šarić 2014; Forenbaher, Perhoč 2015,2017; Kozlowski, Kaczanowska 2015; Tykot 2014; Dogiama 2018; Starnini et al. 2018; Podrug et al. in press a; background map by $F$. Tessier). 
The Gargano promontory, covering an area of about $2000 \mathrm{~km}^{2}$, is situated on the western shore of Adriatic in the vicinity of the Tavoliere plain, where one of the earliest Neolithic sites in Italy were documented.

A large network of at least twenty mining sites have been discovered, mostly located on the north-eastern part of the Gargano promontory (between Vieste and Peschici), whose exploitation was dated from the Early Neolithic to the Early Bronze Age, c. 6000-2000 cal BC (Di Lernia et al. 1995; Galiberti 2005; Tarantini, Galiberti 2011; Tarantini et al. 2016). Three geological Gargano formations were exploited by prehistoric miners: the Maiolica, Scaglia and Peschici formations (Tarantini et al. 2017). In this region homogenous cherts are abundant, and occur either as large lenticular nodules (Peschici Nummulite platform) or in the form of spherical and irregular nodules (Maiolica and Scaglia) (for details see Taranti$n i$ et al. 2017).

The Defensola site, situated on the Gargano promontory, is considered to be the oldest mine in Europe. Radiocarbon dates indicate that this underground mine was used at least from c. 5800-5700 cal BC ( $D i$ Lernia et al. 1995.126-130; Guilbeau 2010.51; Tarantini et al. 2017.253) and many Impressa sherds have been collected from here.

With regard to the current state of research, there is no evidence pointing to the complex exploitation of such cherts (from the primary sources requiring mining activities) during the Mesolithic.

\section{The organisation of lithic blade production in Neolithic Northern Dalmatia}

The organisation of lithic production, reflected in the prehistoric knapper's intentions, implies the concept of schéma and chaîne opératoire as well as the concepts of raw-material economy and débitage economy, and thus examines the lithic artefacts, from their extraction to final consumption (Leroi-Gourhan 1965; Inizan 1980; Perlès 1980; 1990; Soressi, Geneste 2011).

\section{Raw material procurement}

Due to the pioneering work of Perhoč, systematic geoarchaeological and petrographic investigations of chert outcrops and artefacts were initiated in the region (Perhoč 2009ab; Perhoč, Altherr 2011; Forenbaher, Perhoč 2015, 2017; Vukosavljević et al. 2014; Vukosavljević, Perhoč 2017; Vujević et al. 2017).
According to recent research, during the Neolithic the Gargano cherts (and specifically the Maiolicatype cherts of Upper Jurassic-Lower Cretaceous age) were almost exclusively used in the production of blades (Forenbaher, Perhoč 2015; 2017.193; Mazzucco et al. 2018; Podrug et al. in press a; in press b; Kačar 2019; pers.com. Z. Perhoč).

Nevertheless, detailed petrographic characterisation and source identification are often problematic, since a thick white patina covers the majority of artefacts (Forenbaher, Perhoč 2015; 2017; Podrug et al. in press $a$; in press b; Kačar 2019). However, that is not the case for the artefacts from Crno Vrilo, as their primary appearance has stayed unchanged. This assemblage shows an important variability in the colour and structure of this Upper Cretaceous chert that might indicate different sources of procurement within the Gargano area, although these claims need to be confirmed by more detailed petrographic analysis.

It is important to note that, despite the existence of the seemingly well-organized network of Gargano chert distribution, the Lipari obsidian does not reach the Dalmatian shore before the Middle Neolithic Danilo culture (Tykot 2015; Podrug et al. in press b).

Besides this exogenous chert, the local Dalmatian cherts are also represented but in smaller quantities and almost exclusively evidenced by flakes and debris. The site of Konjevrate seems to be an exception, since local cherts prevail in the assemblage, but its stratigraphy was recently revisited confirming the pre-Neolithic attribution of these industries (Podrug, Kačar in press).

\section{Lithic blade production}

From the very beginning of the Neolithic period in the Eastern Adriatic, the lithic production was orientated towards blade production (Müller 1994; Forenbaher, Perhoč 2015; 2017; Mazzuco et al. 2018; Podrug et al. in press a).

The regularity of the blade edges and ridges and constant thickness indicate the use of pressure flaking. According to the lithic assemblages under study here, an average prismatic blade would have been around $14.6 \mathrm{~mm}$ wide and about $3.8 \mathrm{~mm}$ thick, and its average length around $48.4 \pm 22.3 \mathrm{~mm}$ (Tab. 4). Figure 4 indicates that the débitage aimed to produce bladelets and blades between 10 and $16 \mathrm{~mm}$ wide.

Based on his experiments, Pelegrin has defined several pressure flaking processes related to the width 
of the blade blanks (Pelegrin 1988; 2012.468). The wider the blade is, the stronger must be the pressure exerted to detach the blade. Thus different tools were used in order to develop pressure of different intensities, with each tool corresponding to a certain 'mode' (for details see Pelegrin 1988; 2012.468).

Most (60\%) of the Early Neolithic blades from our assemblages evidence the use of a long crutch used in a standing position (mode 4, according to Pelegrin), as their width is between 12 and $16 \mathrm{~mm}-$ and several pieces reach almost $20 \mathrm{~mm}$ in width (Fig. 4). The best examples of large blades come from Crno Vrilo, where a few blades of impressive dimensions are preserved. The longest complete example measures $156 \mathrm{~mm}$ (Korona 2009.154). Along with these specimens there are dozens of pieces whose width exceeds $20 \mathrm{~mm}$ (Fig. 4). According to Pelegrin's experiments, these specimens could not be detached by abdominal pressure alone (mode 4), since the long crutch used in the standing position cannot provide the necessary pressure.

According to traditional experiments, those blades could have been made by indirect percussion or by a more complex pressure mode (mode 5, according to Pelegrin), which consists of the use of a lever device. However, recently, Heredia managed to obtain, in a non-systematic way and with certain difficulties, a few of larger blades (up to $28 \mathrm{~mm}$ ) by abdominal pressure alone, using the crutch with a copper tip in the standing position (mode 4, according to Pelegrin; https://www.youtube.com/watch?v=5kvgaEH-Ll0).

While pressure flaking characterizes the Dalmatian blade production, the use of indirect percussion is harder to demonstrate. However, we think that for some specimens, and especially those detached in order to repair the knapping surface (Pl. 2.1-4), the use of indirect percussion cannot be ruled out. On the other hand, the regularity and straightness of some blanks and their constant thickness point instead to the use of lever pressure (mode 5, according to Pelegrin; Pl. 1.1,2,4). The use of lever pressure is usually suggested for the production from later periods, for example, the Chalcolithic big blades from Karanovo V-VI (Manolakakis 1994). However, such broad blanks are reported since the Early Neolithic in Southern Italy (Guilbeau 2011; Collina 2015) and in Greece (Perlès 1990; Guilbeau, Perlès 2016).

Although the blade cores are absent from the assemblages, the morphology of the blade blanks can in- dicate their form. They were of cylindrical or subconical shapes and débitage was always unipolar. The proximal parts of the blades (butts) indicate that the preparation of the striking platform was not systematic (butts are mostly plain and compose $45 \%$ of the assemblage, followed by linear with $25 \%$ ), but the overhangs were carefully removed.

Except in Crno Vrilo, lithic finds are scarcely represented in the Dalmatian Early Neolithic assemblages, making the reconstruction of schéma and chaines opératoire somewhat difficult. However, it seems that the Dalmatian assemblages display always partial chaînes opératoires, i.e. some technical stages are always missing. Indeed, as already mentioned, the blade cores are always absent while the scarcity of cortical pieces, especially the large and thick ones pointing to decortication, trimming and shaping of the cores, implies that the first stages of reduction occurred somewhere else.

Nevertheless, in the assemblages we studied, at least for some sites, there are some elements pointing to the possibility of in situ production. The presence of flakes, cortical flakes and debris, and specifically of technological pieces as core tablets, crested blades, overshot blades and core renewal flakes and blades, could indicate the local production of blades (Tab. 2).

The presence of flakes (especially those bearing laminar negatives on the dorsal side) indicates in situ production, but one must keep in mind that pressure flaking produces few flakes. In this, the flakes are usually produced during the first stages of chaine opératoire, i.e. core preparation, while small corrections of débitage surface/striking platform are most often realized by detachments of thin laminar flakes or small bladelets (Pl. 1.15). The presence, although rare (only 13 pieces from Crno Vrilo assemblage) of flakes bearing laminar negatives on the dorsal side, but which seem not to have been detached in order to rejuvenate the core, might indicate that, after blade production, the exploitation of the cores continues in order to obtain flakes. These flakes, as well as those made of local cherts, could suggest an ad $h o c$ or expedient production, with the expedient products being those that "have been manufactured, used, and discarded over a relatively short time period" (Binford 1977). If this was a case, we can consider that the Early Neolithic people from Dalmatia were acquiring (more or less prepared) cores, and not exclusively finished semi-products. We have noted at least three flake cores on Gargano chert (Tab. 2; Pl. 1.16). 
However, we cannot conclude that all the blades were produced in situ. While this may be suggested for blades obtained by abdominal pressure flaking (mode 4), for large blades ( $\geq 20 \mathrm{~mm}$ ), and especially if we consider that they were produced by lever pressure, the introduction as finished semi-products could not be ruled out. Following criteria established

\begin{tabular}{|c|c|c|c|c|c|c|}
\hline & & 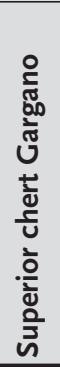 & 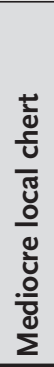 & 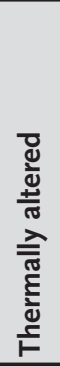 & 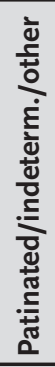 & $\begin{array}{l}\frac{U}{\pi} \\
\frac{\pi}{0} \\
\frac{\pi}{0} \\
\stackrel{0}{0}\end{array}$ \\
\hline \multirow{11}{*}{ 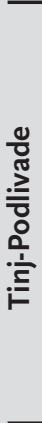 } & Blades & 16 & & 2 & & 18 \\
\hline & Cortical blades & 4 & & & & 4 \\
\hline & Core renewal blades & 4 & & & & 4 \\
\hline & Flakes & 35 & 1 & 4 & & 40 \\
\hline & Cortical flakes & 4 & & & & 4 \\
\hline & Core renewal flakes & 4 & & & & 4 \\
\hline & Cores & & & & & \\
\hline & Debris & 21 & 2 & 3 & & 26 \\
\hline & Small flakes $(\geq 1 \mathrm{~cm})$ & 1 & & & & 1 \\
\hline & Tested blocs & & & & & \\
\hline & Total & 89 & 3 & 9 & & 101 \\
\hline \multirow{11}{*}{ 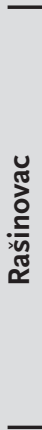 } & Blades & 11 & & 1 & 1 & 13 \\
\hline & Burin spalls & 1 & & & & 1 \\
\hline & Core renewal blades & 1 & & & & 1 \\
\hline & Flakes & 12 & 12 & 1 & 2 & 27 \\
\hline & Cortical flakes & & 4 & & 2 & 6 \\
\hline & Core renewal flakes & 3 & & & 1 & 4 \\
\hline & Cores & & 1 & & & 1 \\
\hline & Debris & 5 & 10 & & 2 & 17 \\
\hline & Small flakes $(\geq 1 \mathrm{~cm})$ & & & & & \\
\hline & Tested blocs & & & & & \\
\hline & Total & 33 & 27 & 2 & 8 & 70 \\
\hline \multirow{11}{*}{$\frac{\mathfrak{3}}{\frac{\pi}{2}}$} & Blades & 40 & & & & 40 \\
\hline & Cortical blades & 9 & & & & 9 \\
\hline & Core renewal blades & 4 & & & 1 & 5 \\
\hline & Flakes & 24 & & & 3 & 27 \\
\hline & Cortical flakes & 3 & & & 1 & 4 \\
\hline & Core renewal flakes & 6 & & & & 6 \\
\hline & Core & 1 & 1 & & & 2 \\
\hline & Debris & 2 & 3 & & 1 & 6 \\
\hline & Small flakes $(\geq 1 \mathrm{~cm})$ & & & & & \\
\hline & Tested blocs & & & & & \\
\hline & Total & 89 & 4 & & 6 & 99 \\
\hline
\end{tabular}

Tab. 2. Lithic assemblage breakdown by main raw material groups and technological categories (simplified). The group 'patinated, indeterminate, other' clusters the raw materials which could not be identified due to heavy patina or raw material types for which only a few pieces have been found. For this paper different types of local/regional cherts from Konjevrate were regrouped together as 'local cherts' since, according to new excavations, these industries are pre-Neolithic. The technical group 'core-renewal flakes' chusters flakes testifying to blade débitage (elements of reparations and flakes with blade's negatives). by Perlès (1990.27; 2001.208) the lever pressured blades suggest high technological investment and obvious socio-economical specialization. Those blades must have been produced by specialized, well-trained knappers possessing the necessary equipment and who invested time in order to obtain the important knowledge and know-how needed for mastering the

\begin{tabular}{|c|c|c|c|c|c|c|}
\hline & & 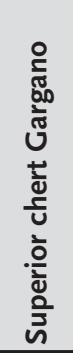 & 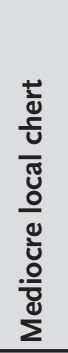 & 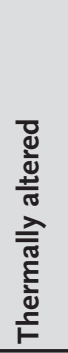 & 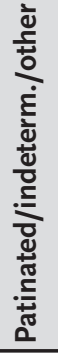 & $\frac{\frac{u}{\frac{0}{\pi}}}{\frac{0}{\pi}}$ \\
\hline \multirow{12}{*}{ 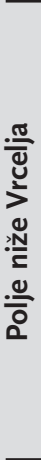 } & Blades & 10 & & 2 & 9 & 21 \\
\hline & Cortical blades & 1 & & & 2 & 3 \\
\hline & Core renewal blades & 3 & & & 1 & 4 \\
\hline & Burin spalls & & & & 1 & 1 \\
\hline & Flakes & 30 & & 7 & 15 & 52 \\
\hline & Cortical flakes & 4 & & & 4 & 8 \\
\hline & Core renewal flakes & 10 & & & 7 & 17 \\
\hline & Core & 1 & & & & 1 \\
\hline & Debris & 25 & & 5 & 20 & 50 \\
\hline & Chips & 1 & 1 & & 3 & 5 \\
\hline & Tested blocs & 1 & 2 & & & 3 \\
\hline & Total & 86 & 3 & 14 & 62 & 165 \\
\hline \multirow{13}{*}{ 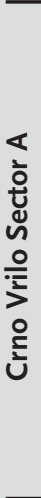 } & Blades & 200 & & 29 & 26 & 255 \\
\hline & Cortical blades & 14 & & 1 & 2 & 17 \\
\hline & Core renewal blades & 10 & & 2 & 3 & 15 \\
\hline & Burin spalls & 21 & & & 1 & 22 \\
\hline & Flakes & 405 & 82 & 79 & 48 & 614 \\
\hline & Cortical flakes & 47 & 21 & 9 & 6 & 83 \\
\hline & Core renewal flakes & 135 & & 23 & 7 & 165 \\
\hline & tablet & 9 & 2 & 1 & & 12 \\
\hline & Core & 1 & 10 & 1 & & 12 \\
\hline & Debris & 96 & 25 & 38 & 21 & 180 \\
\hline & Small flakes $(\geq 1 \mathrm{~cm})$ & 32 & & & 4 & 36 \\
\hline & Tested blocs & & 1 & & & 1 \\
\hline & Total & 970 & 141 & 183 & 118 & 1412 \\
\hline \multirow{13}{*}{ 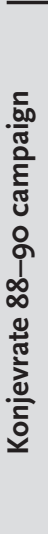 } & Blades & 12 & 34 & & 2 & 48 \\
\hline & Cortical blades & 1 & 6 & & & 7 \\
\hline & Core renewal blades & 3 & 13 & & 1 & 17 \\
\hline & Burin spalls & & 3 & & & 3 \\
\hline & Flakes & 24 & 228 & 11 & 44 & 307 \\
\hline & Cortical flakes & 3 & 74 & 4 & 9 & 90 \\
\hline & Core renewal flakes & 8 & 66 & 3 & 7 & 84 \\
\hline & Cores and fragments & 1 & 67 & & 4 & 72 \\
\hline & - of which for blades & & 18 & & & \\
\hline & $\begin{array}{l}\text { Debris and natural } \\
\text { pieces }\end{array}$ & 2 & 155 & 7 & 16 & 180 \\
\hline & Small flakes $(\geq 1 \mathrm{~cm})$ & & & & & \\
\hline & Tested blocs & & 5 & & & 5 \\
\hline & Total & 54 & 651 & 25 & 83 & 813 \\
\hline
\end{tabular}


core preparation as the technologically most demanding part of the chaîne opératoire.

But is it possible to demonstrate that one population of blades (and namely the 'large' ones) were introduced as finished semi-products while others were produced in situ?

For example, in the Crno Vrilo assemblage cortical and corerenewal blades, i.e. pieces that might indicate in situ production, are represented with 32 pieces, whereas the width of eight specimens exceeds $20 \mathrm{~mm}$

(Fig. 5). Two different hypothesis can be proposed to explain the presence of those specimens. According to the first, the production occurred in situ and those specimens point to the beginning of blade débitage or to the core renewal (technical pieces). The second hypothesis implies that the production occurred somewhere else (and not on the site) and that the blades that we consider today as 'technical' were also circulating as finished products. This was sometimes observed in other Neolithic contexts, like in the Chasséen of Southern France. Here the regular presence of core renewal blades suggests that the robustness of blanks is sought more than their regularity (Léa 2004.135, 147, 164, 169). Besides, in the Crno Vrilo assemblage six specimens that refer either to cortical or core renewal blades (including two 'larges' ones) are retouched and/or glossy, while seven others (including two 'larges' ones) have very worn edges, probably indicating their use. Moreover, use-wear analysis of the harvesting techniques on the Dalmatian impressed ware assemblages has shown that the different types of blades and bladelets (central, cortical and technical) have been intentionally segmented for use as sickle elements (Mazzucco et al. 2018).

On the other hand, and since we consider that for some technical pieces the use of indirect percussion cannot be ruled out, it is possible that some large blades were produced in situ while others (made by lever pressure flaking) could have been introduced as finished semi-products. Future research is needed to clarify the matter.

\section{Tools}

With the introduction of farming, the technical needs of prehistoric societies changed, as witnessed in the lithic tool assemblages. The lithic débitage was now orientated towards blade production in order to obtain long, regular and thin blanks that can could hafted onto the wooden or bone handles as sickle implements. The traces of use and the dullness of once sharp edges indicate that the majority of blades were used blank. The intensive use of blank blades in various activities could produce non-intentional retouch. For that reason, exhaustive typological analyses of Neolithic lithic assemblages are not necessary, but a combined typo-functional approach is needed.

Impressed ware assemblages from Northern Dalmatia indicate that the tools are mostly made on blades (Tab. 3). In most cases (46\%) the retouches were not carefully made and the majority of tools can be regrouped as 'pieces with irregular removals'. Other tool groups can be divided as follows: blades with continuous semi-abrupt retouches (11\%), blades and bladelets with abrupt retouches (less frequent 6\%), drills and 'becs' (pointed blades with abrupt and semiabrupt retouches: $7 \%$ ), truncations (2\%), bitruncations and geometrical trapezes (6\%, almost exclusively symmetrical, with no use of the microburin technique), and burins and burin spalls (almost only evidenced in the Crno Vrilo assemblage, where it represents $19 \%$ of all tools). Glossy blades are well represented in almost all assemblages $(33 \%$ of all tools). In Crno Vrilo, for example, $21 \%$ of all blades from sector A are characterized by a so-called 'sicklegloss', although their presumed function is yet to be characterized.

The notched blades, the typical tools of Castelnovian assemblages, with notches resulting from a voluntary 
retouch (Gassin et al. 2013), are almost completely absent from Early Neolithic lithic assemblages. On the other hand, the production of trapezes continued during the impressed ware phase, and these bitruncated blade fragments are represented with at least 14 pieces (Tab. 3). However, the Castelnovian trapezes are usually made with the microburin technique and are symmetrical, whereas the Early Neolithic ones do not use this technique and are less standardized as they generally come in various forms and shapes.

Tools made on flakes will not be discussed here, but it can be stated that flake assemblages consist mainly of expedient tools characterized by retouched flakes, scrapers and splintered pieces.

Early Neolithic lithic production and its relevance to the Neolithisation of the Eastern Adriatic

From the very beginning of the Neolithic period in both Dalmatia and Apulia, the blade production is characterized by pressure flaking on Gargano cherts (Collina 2009; 2015; Guilbeau 2010; 2011; Forenbaher, Perhoč 2015; 2017; Mazzucco et al. 2018; Podrug et al. in press a; Kačar 2019).

Indirect percussion seems to be used to a much lesser extent and perhaps mainly for repairing the knapping surface or detaching the blades, which would have been too difficult to detach by pressure (Collina 2009; 2015; Kačar 2019).
As we have seen, both techniques are known from the Late Mesolithic, but the Early Neolithic lithic production is characterized by more complex procurement strategies, as evidenced in the development of sophisticated raw material economy (Binder 1987; Perlès 1990; 1991; 2009; Allard 2007.219; Perrin 2009: 518; Perrin, Binder 2014; Kačar 2019).

There is no evidences of complex mining during the Mesolithic, neither on the Italian nor Croatian sides of the Adriatic. It is true that the Mesolithic sites and specifically those belonging to its late phase are rather scarce in the Adriatic region, but even where the Castelnovian is surely attested (Uzzo, Latronico, Edera, Crvena Stijena, Odmut) there are no indications of complex strategies involving interregional networks of raw material procurement (Collina 2009; Mihailović 2009; Kačar 2019). Instead, the production of blade blanks relies on local sources of procurement, such as pebbles of small to medium size.

The dominance of Gargano cherts in Dalmatia and Apulia assemblages reinforces the idea of cultural unity under the (Italo-Dalmatian) impressed ware

\begin{tabular}{|c|c|c|c|c|c|c|c|c|c|}
\hline & $\begin{array}{l}\text { Crno } \\
\text { Vrilo }\end{array}$ & Rašinovac & Vrbica & Tinj & Vrcelji & $\begin{array}{c}\text { Konjevrate } \\
\text { Gargano }\end{array}$ & $\begin{array}{c}\text { Konjevrate } \\
\text { other }\end{array}$ & TOTAL & $\%$ \\
\hline Pieces with irregular removals & 72 & 4 & 12 & 5 & 3 & 4 & 3 & 103 & 46 \\
\hline Notched pieces & 4 & & 1 & & & & & 5 & 2,2 \\
\hline Pieces with abrupt retouch & 8 & 2 & & & & 1 & 2 & 13 & 5,8 \\
\hline Pieces with semi-abrupt retouch & 13 & & 2 & & 3 & 1 & 6 & 25 & 11,2 \\
\hline Borers and drills & 14 & 1 & & & & & & 15 & 6,7 \\
\hline Truncations & 4 & 1 & & & & & & 5 & 2,3 \\
\hline Bitruncations & 8 & 1 & & 4 & 1 & & & 14 & 6,3 \\
\hline Burins and burin spalls & 29 & 1 & & & 2 & & 3 & 35 & 15,6 \\
\hline Scrapers & 3 & & 3 & & & & 3 & 9 & 4 \\
\hline Total tools on blades & 155 & 10 & 18 & 9 & 9 & 6 & 17 & 224 & 100 \\
\hline of which glossy blades & 61 & 1 & 6 & 2 & 2 & 1 & & 73 & 32,5 \\
\hline
\end{tabular}

Tab. 3. Tools on blades: typological breakdown. 


\begin{tabular}{|c|c|c|c|c|c|}
\hline & & & 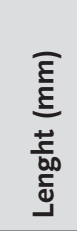 & $\begin{array}{l}\bar{\xi} \\
\underline{\xi} \\
\overline{5} \\
\frac{ \pm}{0}\end{array}$ & 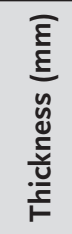 \\
\hline \multirow{18}{*}{ 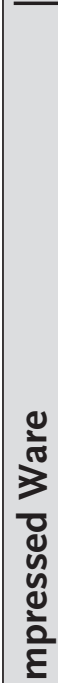 } & \multirow{5}{*}{ Rašinovac } & no. & 1 & 14 & 14 \\
\hline & & Minimum & 37,6 & 7,1 & 1,6 \\
\hline & & Maximum & 37,6 & 24,5 & 5,9 \\
\hline & & Average & 37,6 & 13,3 & 3,6 \\
\hline & & SD & & 4,6 & 1,1 \\
\hline & \multirow{5}{*}{ Vrbica } & no. & 6 & 54 & 54 \\
\hline & & Minimum & 31,9 & 6 & 1,7 \\
\hline & & Maximum & 71,8 & 24,3 & 10,6 \\
\hline & & Average & 55 & 15,2 & 4,3 \\
\hline & & SD & 17,4 & 3,7 & 1,9 \\
\hline & \multirow{5}{*}{$\begin{array}{l}\text { Crno Vrilo } \\
\text { (Sector A) }\end{array}$} & no. & 33 & 280 & 287 \\
\hline & & Minimum & 28,8 & 4,1 & 0,9 \\
\hline & & Maximum & 132,5 & 27,8 & 8,5 \\
\hline & & Average & 50,9 & 14,1 & 3,7 \\
\hline & & SD & 21,5 & 5,1 & 1,3 \\
\hline & \multirow{5}{*}{$\begin{array}{l}\text { Tinj- } \\
\text { Podlivade }\end{array}$} & no. & 2 & 26 & 26 \\
\hline & & Minimum & 9,1 & 4,1 & 2,3 \\
\hline & & Maximum & 84,6 & 31,5 & 7 \\
\hline \multirow{17}{*}{ 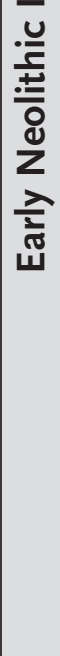 } & & Average & 46,9 & 16,8 & 4,1 \\
\hline & & SD & 53,4 & 6,1 & 1,4 \\
\hline & \multirow{5}{*}{$\begin{array}{l}\text { Polje niže } \\
\text { Vrcelja }\end{array}$} & no. & 7 & 28 & 28 \\
\hline & & Minimum & 17,3 & 5,5 & 1,8 \\
\hline & & Maximum & 50,3 & 19,3 & 8,6 \\
\hline & & Average & 34,2 & 12,8 & 3,7 \\
\hline & & SD & 10,7 & 3,3 & 1,7 \\
\hline & \multirow{5}{*}{$\begin{array}{l}\text { Konjevrate } \\
\text { (campaign } \\
\text { 1988-1990) }\end{array}$} & no. & 1 & 15 & 15 \\
\hline & & Minimum & 36,4 & 6,9 & 1,6 \\
\hline & & Maximum & 36,4 & 26,3 & 8,3 \\
\hline & & Average & 36,4 & 14 & 4 \\
\hline & & SD & & 4,2 & 1,9 \\
\hline & \multirow{5}{*}{ All sites } & no. & 50 & 417 & 424 \\
\hline & & Minimum & 9,1 & 4,1 & 0,9 \\
\hline & & Maximum & 132,5 & 31,5 & 10,6 \\
\hline & & Average & 48,4 & 14,6 & 3,8 \\
\hline & & SD & 22,3 & 4,6 & 1,4 \\
\hline
\end{tabular}

Tab. 4. Blades and bladelets metric data. The length was measured only for complete specimens.

ceramic style. The Gargano network spread over South Italy and Dalmatia at the same time, and since the very start of the $6^{\text {th }}$ millennium BC (Collina 2009; 2015; Guilbeau 2010; 2011; Forenbaher, Perhoč 2015; 2017).

This date points to the very beginning of the Neolithisation of the whole Adriatic region. The presence of Gargano cherts in Eastern Adriatic assemblages raises many questions, especially why and how this raw material arrived in Dalmatia. Was it necessary because of the lack of good quality raw material or the lack of (locational) knowledge? Or was it a choice due to the social and/or symbolic value of exogenous material?

First of all, according to Perhoč's research there are no comparable (by quality and nodule size) cherts in the Dalmatia, nor in the adjacent regions (Perhoc 2009ab; Perhoč, Altherr 2011; Forenbaher, Perhoc 2015; 2017.205; Vukosavljević et al. 2014; Vukosavljević, Perhoč 2017; Vujević et al. 2017; Podrug et al. in press $a$; in press $b)^{1}$. This implies that Gargano cherts were a rare good. In this sense, the preference for Gargano cherts in Dalmatia can be interpreted by a relative poverty of raw material suitable for complex pressure flaking (Forenbaher, Perhoc 2017.204-205; Mazzucco et al. 2018; Kačar 2019). However, this does not imply that the Gargano chert distribution has only an economic (utilitarian) role and thus the social aspects of such networks cannot be neglected (Perlès 1990; 2001; 2007; 2009; Forenbaher, Perhoč 2017.206; Kačar 2019). On the contrary, the hypothesis of a cultural choice, revealing a social rather than a techical logic (Perlès 2009), must be privileged. Or, as Forenbaher and Perhoč recently concluded "Perhaps the true value and purpose of the trans-Adriatic exchange of Gargano cherts was to maintain social networks that linked the small farming communities scattered around the Adriatic shores and islands" (Forenbaher, Perhoč 2017.206).

According to the same authors, the existence of a Gargano network of distribution from the very beginning of the $6^{\text {th }}$ millennium might hint to the WestEast direction of Neolithisation (from Apulia to Dalmatia), supporting the hypothesis that migration played an important role in spread of farming ( $\mathrm{FO}^{-}$ renbaher, Perhoč 2017.204).

In this sense the domination of Gargano cherts in the southern Dalmatia as documented in Nakovana cave was interpreted as indicating that the early Neolithic occupants of the cave were recent arrivals, not yet possessing the necessary locational knowledge (Forenbaher, Perhoč 2015.66; 2017.204).

However, although these claims sound plausible, one should keep in mind that reliable current radiocarbon dates show no temporal priority of Italian sites and that many data points are probably lost due to the Holocene sea-level rise.

1 However, according to Perhoč's publication (2009b.48, Fig. 2), one can note the existance of good-quality chert of non-negligible size $(c .10 \mathrm{~cm})$ in southern Dalmatia (Stračinčica, Vela Luka, Korčula). 
In order to understand the nature of social interactions between western and eastern shores of Adriatic which might illustrate the alternative routes of Neolithisation, it is necessary to see in which form Gargano cherts arrived in Dalmatia (as finished semiproducts or as blade cores) and how they were distributed (by direct or indirect procurement?).

Unfortunately, we have seen that, according the current state of research, it is not clear in which form Gargano cherts reach Dalmatia. However, unlike Forenbaher and Perhoč $(2015 ; 2017)$, who concluded that the Gargano blades arrived as finished semiproducts, we think that the presence of some elements pointing to blade production in situ might also indicate the acquisition of cores, i.e. blade blanks were not exclusively imported.

This implies that the chaines operatoires of the Dalmatian and South Italian assemblages do not differ substantially, since the Gargano cherts were introduced into the Italian sites as partially worked blocs/ cores in the initial phase or finished blanks, and never as raw materials (Collina 2009; Guilbeau 2010; 2011).

It can thus be presumed that the first phases of reduction (decortication and trimming) were conducted near or inside the mines (Di Lerna et al. 1995; Tarantini et al. 2016). The shaped blocs, or even more or less finished cores, could then be distributed over the land and sea. This preparation would facilitate transportation (since the merchandise would have been less heavy) and at the same time ensure the quality of the blocs ( $c f$. Perlès 1990.27).

But how were the cherts further distributed? As already mentioned, all the southern Italian assemblages that have been studied with regard to the raw material economy, and even those situated closest to the Gargano mines (Ripa Tetta) or closest to the littoral (Scamuso), lack any evidence of primal reduction (Collina 2009; 2015). Following this and taking into account the important presence of Gargano artefacts at the Crno Vrilo site, a simple down-the-line distribution (Renfrew 1984) should be ruled out.

Besides, the long-distance procurement that requires navigation skills and some complex logistical organisation provides more supports for the idea of trade than direct acquisition (Perlès 1990.17-23; 1992. 110).

It is therefore reasonable to assume that the Gargano mines were held and exploited by a limited group of specialist who controlled the chert distribution as well (Tarantini et al. 2016).

If the chert was distributed in the form of more and less prepared cores, then this implies that the most demanding part of the débitage (core preparation) occurred out of the consumer sites. The consumer sites would then receive prepared cores and only needed to detach the blades. This final task - blade detaching - is actually the easiest part of pressure flaking débitage (Binder, Perlès 1990.266; Perlès 2007.57; Abbès 2013).

However, we cannot exclude the possibility of intermediary site(s) where the blades were produced for trade. One part of Gargano artefacts was probably circulated as finished products and the lever pressured blades could have been traded this way ( $\mathrm{Col}$ lina 2009; 2015; Forenbaher, Perhoč 2015; 2017; Mazzucco et al. 2018; Kačar 2019). Those sites could have been located on the coast and thus today would be submerged.

The blades manufactured with lever pressure seem to be present in Dalmatia since the very beginning of the Neolithic. They are reported at the oldest levels of Pokrovnik, dated to $c .6000$ cal BC (Mazzuco et al. 2018). The technique of lever pressure is undoubtedly a Neolithic innovation: it is recorded in a few Neolithic contexts, but never earlier (Pelegrin 2006; Guilbeau, Perlès 2016.3).

To sum up, although the size and the means of the Gargano chert distribution network and its relevance to the Neolithisation dispersion routes have yet to be solved, it is clear that this complex economy of raw material reflects social choices that are specific to the Neolithic.

Moreover, even though the pressure blade flaking technology emerged in the Balkans during the $7^{\text {th }}$ millennium, as witnessed in the Montenegrin Late Mesolithic Castelnovian industries (with the blank size pointing to the use of a short crutch, mode 3 , according to Pelegrin 1988; 2012), at the onset of Neolithic period more complex modes (modes 4 and 5 according to Pelegrin 1988; 2012) of pressure flaking were developed in connection with a new interregional procurement network centred in the Gargano area. It thus seems that we may be dealing with two distant phenomena of probably different origins. The origin of Castelnovian pressure blade production might be in North Africa (Marchand, Perrin 2017), whereas impressed ware pressure blade production is closely connected to processes of Neo- 
lithisation. The latter shows great connections with Italian impressed ware industries and Greek Early Neolithic industries, both in complex raw material procurement strategies and production techniques, and might thus originate from the Near-East (Turkey or Levant) (Perlès 1990; 2001; Binder 2007; Guilbeau 2010; 2011; 2017; Guilbeau, Perlès 2016; Horejs et al. 2015). In other words, the Early Neolithic blade production of Dalmatian impressed ware should be considered as integral part of the Neolithic package, showing no connections to the Castelnovian or any other Mesolithic lithic traditions.

\section{Conclusion}

Interactions between the eastern and western shores of the Adriatic seemed to have maintained the Neolithisation process in this part of Mediterranean: the importation of Gargano cherts in Dalmatian lithic assemblages parallels the expansion of the Impressed ware culture and the new type of economy, based on subsistence production. The beginning of the Neolithic period in Dalmatia is thus characterized by profound economic, technical, social and cultural changes that also affected lithic assemblages, since the earliest impressed ware lithic production shows no links to the previous periods.

\section{ACKNOWLEDGEMENTS}

The author would like to thank Zlatko Perhoč, Stašo Forenbaher, Catherine Commenge, Denis Guilbeau, Emil Podrug, Thomas Perrin, Nicolas Tardy, Frederic Abbès, Jacqueline Balen, Marcel Burić, Natalija Čondić, Ivana Galović, Kristina Horvat, Jelena Jović, Florine Marchand, Sarah McClure, Jean Vaquer, Jakov Vučić and Dario Vujević for their help and to a reviewer, Boris Kavur, for his comments, which have helped to improve the paper.

\section{References}

Abbès F. 2013. Quelques réflexions sur les débitages de lame de silex par pression. ArchéOrient-Le Blog (Hypotheses.org), 27 septembre 2013.

http://archeorient.hypotheses.org/1672

Allard P. 2007. Mesolithic- Neolithic transition in Paris Basin: A review. In A. Whittle, V. Cummings (eds.), Going over. Mesolithic-Neolithic transition in Northern Europe. Proceedings of the British Academy 144. Oxford University Press. Oxford: 209-221.

Bass B. 1998. Early Neolithic offshore accounts: remote islands, maritime exploitations, and the trans-Adriatic cultural network. Journal of Mediterranean Archaeology 11(2): 165-190.

Batović Š. 1979. Jadranska zona. In A. Benac (ed.), Praistorija jugoslavenskih zemalja 2: Neolitsko doba. Akademija nauka i umjetnosti Bosne i Hercegovine. Sarajevo: $62-127$.

Benac A. 1955. Crvena Stijena (I-IV stratum). Glasnik Zemaljskog muzeja Bosne i Hercegovine. Arheologija XIII: 19-50.

Biagi P. 2003. The Late Mesolithic in Italy. In A. J. Ammerman, P. Biagi (eds.), The Widening Harvest: The Neolithic Transition in Europe: Looking Back, Looking Forward. Colloquia and Conference Papers 6. Archeological Institute of America. Boston, Massachusetts: 133-156.
Binder D. 1987. Le Néolithique ancien provençal: typologie et technologie des outillages lithiques. Gallia Préhistoire, supplément XXIV. Editions du Centre national de la recherche scientifique. Paris.

2007. PPN Pressure Technology: views from Anatolia. In L. Astruc, D. Binder, and F. Briois (ed.), Technical systems and PPN communities in the near East. Association pour la promotion et la diffusion des connaissances archéologiques. Antibes: 235-43.

2010. Mésolithique et Néolithique ancien en Italie et dans le sud-est de la France entre 7000 et 5500 BCE cal: questions ouvertes sur les dynamiques culturelles et les procès d'interaction. In T. Perrin, C. Manen, G. Marchand, P. Allard, D. Binder, and M. Ilett (eds.), Transitions, ruptures et continuité durant la Préhistoire. XXVIIe Congrès préhistorique de France, session $\mathrm{H}$. Paris. Société Préhistorique Française. Bordeaux: 341-355.

Binder D., Perlès C., Inizan M.-L., and Lechevallier M. 1990. Stratégies de gestion des outillages lithiques au Néolithique. Paléo 2(1): 257-283.

Binder D., Collina C., Guilbert R., Perrin T., and GarciaPuchol 0. 2012. Pressure-knapping blade production in the north-western Mediterranean region during the seventh millennium cal BC. In P. Desrosiers (ed.), The Emergence of Pressure Blade Making. Springer. Boston, Massachusetts: 199-217. 
Binder D. and 23 co-authors 2017. Modelling the earliest north-western dispersal of Mediterranean Impressed Wares: new dates and Bayesian chronological model. Documenta Praehistorica: 44: 54-77.

https://doi.org/10.4312/dp.44.4

Binford L. R. 1977. Forty-seven trips: A case study in the character of archaeological formation processes. In R. V. S. Wright (ed.), Stone tools as cultural markers: change, evolution and complexity. Prehistory and Material Culture. Series 12. Australian Institute of Aboriginal Studies. Canberra: 24-36.

Bressy C. 2003. Caractérisation et gestion du silex des sites mésolithiques et néolithiques du Nord-Ouest de l'arc alpin. Une approche pétrographique et géochimique. British Archaeological Reports IS 1114. Archaeopress. Oxford.

Bronk Ramsey C. 2009. Bayesian Analysis of Radiocarbon Dates. Radiocarbon 51(1): 337-360.

https://doi.org/10.1017/S0033822200033865

Brusić Z. 1995. Naselje iz starijeg neolitika u Vrbici kod Bribira. Diadora 16-17: 1-21.

Chapman J. C., Shiel J. R., and Batović Š. 1996. The Changing Face of Dalmatia. Leicester University Press. London.

Collina C. 2009. Evolution des industries lithiques du Néolithique ancien en Italie du sud. PhD dissertation. University of Provence/ Sapienza University of Rome. AixMarseille 1.

2015. Le Néolithique ancien en Italie du sud. Evolution des industries lithiques entre VIIe et VIe millénaire. Archaeopress. Oxford.

Conati Barbaro B., La Marca C., and Silano C. 2014. La neolitizzazione delle Marche: nuovi dati e prospettive di ricerca. Picus XXXIV: 77-91.

Čečuk B. 1974. Kamene i koštane rukotvorine Markove spilje II. Arheološki radovi i rasprave 7: 221-256.

1976. Kamena i koštana industrija iz Markove spilje. In Batović Š. (ed.), Materijali XII. IX. Kongres arheologa Jugoslavije, Zadar 1972. Hrvatsko arheološko društvo. Zadar: 47-54.

Čečuk B., Radić D. 2005. Vela Spila. Višeslojno pretpovijesno nalazište Vela Luka- otok Korčula. Centar za kulturu "Vela Luka". Vela Luka.

Di Lernia S., Fiorentino G., Galiberti A., and Basili R. 1995. The Early Neolithic mine of Defensola "A" (I18): flint exploitation in the Gargano area. Archaeologia Polonia 33: 119-132.
Dogiama L. 2018. Casting a wide Network: Preliminary resuts from the Early Neolithic Chipped Stone from Ravenia, Pieria, Greece. In A. Sarris, E. Kalogiropoulou, T. Kalayci, and L. Karimali (eds.), Communities, Landscapes, and Interaction in Neolithic Greece. Proceedings of the International Conference, Rethymno 29-30 May, 2015. International Monographs in Prehistory. Archaeological Series 20. Ann Arbor: 446-480.

Ferrari S. 2011. Il Mesolitico recente in Emilia e il complesso culturale castelnoviano: dinamiche insediative e sistemi tecnici litici. Unpublished $\mathrm{PhD}$ dissertation. University of Ferrara. Ferrara.

Fontana A., Corregiari A., and Juračić M. 2014. Il mare Adriatico dall'ultima glaciazione a oggi: evoluzione geomorfologica e aspetti paleoambientali. / The Adriatic Sea from the last glaciation until today: geomorphological evolution and paleoenvironmental aspects. In P. Visentini, E. Podrug (eds.), Adriatico senza confini.Via di comunicazione e crocevia di popoli nel 6000 a.C./The Adriatic, a sea without borders:communication routes of populations in 6000 BC. Civici Musei di Udine. Museo Friulano di Storia Naturale. Udine: 23-41.

Forenbaher S. 2006. Flaked stone artefacts. In P. T. Miracle, S. Forebaher (eds.), Prehistoric Herders of northern Istria. The Archaeology of Pupicina Cave 1/1. Monografije i katalozi 14. Pula: 225-258.

Forenbaher S., Kaiser T. 2008. Grapčeva Spilja: Prapovijesni stan, tor i obredno mjesto (Rezultati arheološkog istraživanja 1996 godine). Književni Krug. Split.

Forenbaher S., Kaiser T., and Miracle P. T. 2013. Dating the East Adriatic Neolithic. European Journal of Archaeo$\log y$ 16(4): 589-609.

https://doi.org/10.1179/1461957113Y.0000000038

Forenbaher S., Miracle P. T. 2005. The Spread of Farming in the Eastern Adriatic. Antiquity 79: 514-528.

https://doi.org/10.1017/S0003598X00114474

2006. Pupićina Cave and the Spread of Farming in the Eastern Adriatic. In P. T., Miracle, S. Forebaher (ed.), Prehistoric Herders of northern Istria. The Archaeology of Pupicina Cave 1/1. Monografije i katalozi 14. Pula: 483-519.

2014. Transition to farming in the Adriatic: a view from the eastern shore. In C. Manen, T. Perrin, and J. Guilaine (eds.), La Transitions en Méditerranée ou comment les chasseurs devinrent agriculteurs (Epipaléolithique, Mésolithique, Néolithique ancien). Actes du colloque, Museum de Toulouse, 14-15 avril 2011. Éditions Errance / Archives d'Écologie Préhistorique. Arles: 71-77. 
Forenbaher S., Perhoč Z. 2015. Lithic artifacts from Nakovana (Pelješac): Continuity and Change from Early Neolithic until the end of Prehistory. Prilozi Instituta za arheologiju 32: 5-74. https://hrcak.srce.hr/148843

2017. Lithic Assemblages from Nakovana (Croatia): Raw Material Procurement and Reduction Technology from the Early Neolithic until the End of Prehistory. Journal of Mediterranean Archaeology 30(2): 189211. https://doi.org/10.1558/jmea.35405

Freund K. P. 2018. A long-term perspective on the exploitation of Lipari obsidian in central Mediterranean prehistory. Quaternary International 468: 109-120. https://doi.org/10.1016/j.quaint.2017.10.014

Gassin B., Marchand G., Claud É., Gueret C., and Philibert S. 2013. Les lames à coches du second Mésolithique: des outils dédiés au travail des plantes? Bulletin de la Société préhistorique française 110(1): 25-46.

Guilaine J. 2005 [1994]. La mer partagée: la Méditerranée avant l'écriture: 7000-2000 avant Jésus-Christ. Hachette Littérature. Paris.

Guilaine J., Gasco J., Evin J., and Valladas H. 2003. Torre Sabea et la chronologie absolue méditerranéenne. In J. Guilaine, G. Cremonesi (eds.), Torre Sabea. Un établissement du Néolithique ancien en Salento. Collection de l'École française de Rome 315. École Française de Rome. Rome : 368-373.

Guilbeau D. 2010. Les grandes lames et les lames par pression au levier du Néolithique et de l'Énéolithique en Italie. Unpublished $\mathrm{PhD}$ dissertation. École doctorale Milieux, cultures et sociétés du passé et du présent, Université Paris Nanterre. http://www.theses.fr/2010PA100146

2011. Le début du Néolithique en Italie méridionale: ce que nous disent les productions en silex du Gargano. Origini XXXIII, Nuova Serie V: 83-106.

in press (2017). The organization of the Aegean first farming communities through the technological study of the chipped stones. The example of Ugurlu-Zeytinlik (Gökçeada Island, Turkey). In Godon M. (ed.), Merging techniques \& cultures. Technological Approaches in Archaeology. Institut Français d'Études Anatoliennes. Istanbul.

Guilbeau D., Erdoğu B. 2011. Des "lames de Karanovo" dans le site neolithique d'Uğurlu (ile de Gökçeada, Turquie). Bulletin de correspondance Hellénique 135: 1-19.

Guilbeau D., Perlès C. 2016. Please help us find the origins of Greek and Italian Early Neolithic lever pressureflaking! Paper presented at the $8^{\text {th }}$ International Confe- rence on PPN Chipped and Ground Stone Industries of the Near East: Near Eastern Lithic Technologies on the Move - Interactions and Contexts in the Neolithic Traditions at the University of Cyprus in Nicosia, 23-27 November 2016.

Guiry E., Karavanić I., Klindžić Šošić R., Talamo S., Radović S., and Richards M. P. 2017. Stable Isotope Palaeodietary and Radiocarbon Evidence from the Early Neolithic Site of Zemunica, Dalmatia, Croatia. European Journal of Archaeology 20(2): 235-256.

https://doi.org/10.1017/eaa.2016.24

Gurova M. 2012. "Balkan flint"- fiction and/or trajectory to the Neolithisation: Evidence from Bulgaria. Bulgarian e-Journal of Archaeology 1: 15-49.

https://be-ja.org/index.php/Be-JA/article/view/56

2014. Neolithic flint assemblages from Bulgaria: an overview. Samarsky nauchny vestnik 3(8): 94-108.

Gurova M., Andreeva P., Stefanova E., Stefanov Y., Kočić M., and Borić D. 2016. Flint raw material transfers in the prehistoric Lower Danube Basin: An integrated analytical approach. Journal of Archaeological Science: Reports 5: 422-441. http://dx.doi.org/10.1016/j.jasrep.2015.12.014

Horejs B., Milić B., Ostmann F., Thanheiser U., Weninger B., and Galik A. 2015. The Aegean in the Early $7^{\text {th }}$ Millennium BC: Maritime Networks and Colonization. Journal of World Prehistory 28: 289-330.

https://doi.org/10.1007/s10963-015-9090-8

Horvat K. 2015. Polje niže Vrcelja - an early Neolithic site in the Benkovac aerea. Vjesnik za arheologiju i historiju dalmatinsku 105: 9-35.

2017. Ambijentalne osnove razvoja neolitičkih zajednica istočnog Jadrana - primjer benkovačkog područja. Unpublished $\mathrm{PhD}$ dissertation. University of Zadar. Zadar.

Inizan M.-L. 1980. Séries anciennes et économie du débitage. Préhistoire et technologie lithique. Publications de l'URA 28, Cahier 1 du CRA. Éditions du Centre national de la recherche scientifique. Paris: 28-30.

Inizan M-L., Redouron-Balinger M., Roche H., and Tixier J. 1999. Technology and terminology of knapped stone. Préhistoire de la pierre taillée. Tome 5. Cercle de recherches et d'études préhistoriques. Nanterre.

Kaczanowska M., Kozłowski J. K. 2008. The Körös and the early Eastern Linear Culture in the northern part of the Carpathian Basin: a view from the perspective of lithic industries. Acta Terrae Septemcastrensis 7: 9-22. 
2017. The Mesolithic lithic industries of the Eastern Adriatic zone. Folia Quaternaria 86: 191-215.

http://www.ejournals.eu/FQ/2018/Vol-86/art/13386

Kačar S. 2019. Les sociétés mésolithiques de l'arc adriatique oriental: des origines à la néolithisation, de l'Istrie aux côtes épirotes. Unpublished $\mathrm{PhD}$ dissertation, University of Toulouse 2- Jean Jaurès/University of Zagreb. Toulouse - Zagreb.

Karavanić I., Šošić Klindžić R., Bunčić M., and Kurtenjak D. 2010. Chipped stone assemblage from the Early Neolithic site of Zadubravlje. Prilozi Instituta za arheologiju u Zagrebu 26(1): 5-20.

Komšo D. 2007. Mezolitik u Hrvatskoj./Mesolithic in Croatia. Opuscula archaeologica 30: 55-92.

2009. Upland colonisation, patterns of settling and habitation in Northern Istria, Croatia. In S. McCartan, R. Schulting, G. Warren, and P. Woodman (eds.), Mesolithic Horizons. Proceedings of the Seventh International Conference on the Mesolithic in Europe. Congress in Belfast (MESO 2005). Oxbow Books. Oxford: 288-295.

Korona M. 2009. Kremeni artefakti. In B. Marijanović (ed.), Crno Vrilo 2. Sveučilište u Zadru. Odjel za arheologiju. Zadar: 145-217.

Kozłowski J. K. 1982. La Néolithisation de la zone balkano-danubienne du point de vue des industries lithiques. In J. K. Kozłowski (ed.), Origin of the Chipped Stone Industries of the Early Farming Cultures in Balkans. Panstwowe Wydawnictwo Naukowe Warszawa. Warszawa-Krakow: 131-170.

Kozłowski J. K., Kaczanowska M. 2015. Mavropigi chipped stone assemblage. In G. Karamitrou-Mentessidi, N. Efstratiou, M. Kaczanowska, and J. K. Kozłowski (eds.), Early Neolithic settlement of Mavropigi in Western Greek Macedonia. Eurasian Prehistory 12(1-2): 71-115.

Kozłowski S. K. 1987. The Pre-Neolithic base of the early Neolithic stone industries in Europe. In J. K. Kozłowski, S. $\mathrm{K}$. Kozłowski (eds.), Chipped stone industries of the early farming cultures in Europe. Papers of the Intern. Symposium/ Warsaw University, Jagiellonian University Cracow, held at Krakow-Mogilany in October 1985. Wydawnictwa Uniwersytetu Warszawskiego. Archaeologia interregionalis. Warsaw: 9-18.

2009. Thinking Mesolithic. Oxbow Books. Oxford.

Léa V. 2004. Les industries lithiques du Chasséen en Languedoc oriental. Caractérisation pour l'analyse technologique. British Archaeological Reports IS 1232. Archaeopress. Oxford.
Leroi-Gourhan A. 1965. Le geste et la parole. Volume 2: la mémoire et les rythmes. Bibliothèque Albin Michel. Sciences.

Manolakakis L. 1996. Production lithique et émergence de la hiérarchie sociale: l'industrie lithique de l'énéolithique en Bulgarie: première moitié du IVe millénaire. Bulletin de la Société préhistorique française 93(1): 119-123.

Marchand G., Perrin T. 2017. Why this revolution? Explaining the major technical shift in Southwestern Europe during the $7^{\text {th }}$ millennium cal. BC. Quaternary International 428: 73-85.

https://doi.org/10.1016/j.quaint.2015.07.059

Marković Č. 1985. Neolit Crne Gore. Centar za Arheološka Istraživanja Filozofskog Fakulteta u Beogradu. Knjiga 5. Univerzitet u Beogradu. Filozofski Fakultet. Beograd.

Marijanović B. 2007. Neka pitanja ranog neolitika istočnog Jadrana. Archaeologia Adriatica 1(1): 7-54.

2009. Crno Vrilo 1. Sveučilište u Zadru. Odjel za arheologiju. Zadar.

Mateiciucová I. with the contribution of Malecka-Kukawska J. 2007. Worked stone: obsidian and flint. In A. Whittle (ed.), The Early Neolithic on the Great Hungarian Plain. Investigations of the Körös Culture site of Ecsegfalva 23, County Békés. Varia archaeologica Hungarica, vol. 21. Institute of Archaeology. Hungarian Academy of Sciences. Budapest: 677-726.

Mazzucco N., Guilbeau D., Kačar S., Podrug E., Forenbaher S., Radić D., and Moore A. 2018. The Time is Ripe for a Change. The Evolution of Harvesting Technologies in Central Dalmatia During the Neolithic Period (6th Millennium cal BC). Journal of Anthropological Archaeology 51: 88-103. https://doi.org/10.1016/j.jaa.2018.06.003

McClure S., Podrug E., Moore M. T. A., Culleton B., and Kennet J. D. 2014. AMS ${ }^{14} \mathrm{C}$ chronology and ceramic sequences of early farmers in the eastern Adriatic. Radiocarbon 56(3): 1019-1038.

https://doi.org/10.2458/56.17918

McClure S. B., Magill C., Podrug E., Moore A. M. T., Harper T. K., Culleton B. J., Kennett D. J., and Freeman K. H. 2018a. Fatty acid specific $\delta^{13} \mathrm{C}$ values reveal earliest Mediterranean cheese production 7,200 years ago. PLOS ONE 13(9): $e 0202807$.

https://doi.org/10.1371/journal.pone.0202807

McClure S. B., Podrug E., and Kennett D. J. 2018b. Radiocarbon Dates from Konjevrate, Croatia. Dataset. https://doi.org/10.18113/S1SS77 
Menđušić M. 1998. Neolitička naselja na šibensko-drniškom području, in: Područje šibenske županije od pretpovijesti do srednjeg vijeka. Znanstveni skup Šibenik 18-20 october 1995. Hrvatsko Arheološko Društvo 19: 47-62.

Mihailović D. 2009. Upper Paleolithic and Mesolithic chipped stone industries from Crvena Stijena. Prehistoric settlements in caves and rockshelters of Serbia and Montenegro, fascicule II. Centre for Archaeological Research. Faculty of Philosophy. University of Belgrade. Belgrade.

Müller J. 1994. Das ostadriatische Frühneolithikum, Die Impresso-Kultur und die Neolithisierung des Adriaraumes. Prähistorische Archäologie in Südosteuropa, Band 9. Wissenschaftsverlag Volker Spiess. Berlin.

Pelegrin J. 1988. Débitage expérimental par pression, "du plus petit au plus grand". In J. Tixier (ed.), Technologie préhistorique. Centre national de la recherche scientifique. Unités de Recherche Associées 28. Éditions du CNRS. Paris: 37-53.

2006. Long blade technology in the Old World: an experimental approach and some archaeological results. Skilled Production and Social Reproduction. Stone Studies 2: 37-68.

2012. New Experimental Observations for the Characterization of Pressure Blade Production Techniques. In P. M. Desrosiers (ed.), The Emergence of Pressure Blade flaking. From origin to modern Experimentation. Springer: 465-500.

Perhoč Z. 2009a. Sources of chert in Middle Dalmatia. Supplying raw material to prehistoric lithic industries. In S. Forenbaher (ed.), A Connecting Sea. A Maritime Interaction in Adriatic Prehistory. British Archaeological Reports IS 2037. Archaeopress. Oxford: 25-47.

2009b. Sources of chert for prehistoric lithic industries in middle Dalmatia. Archeometriai Mühely 6(3): 45-56.

Perhoč Z., Altherr R. 2011. Lithic finds from the Island of Sušac. Opuscula archaeologica 35: 7-35.

Perhoč Z., Ruka R. 2017. Potential Prehistoric Sources of Chert in the Western Lowland of Albania. In Procedings of the International Conference: New Archaeological Discoveries in the Albanian Regions. 30-31 January, Tirana. Academy for Albanian Studies. Institute of Archeology. Tirana: 33-65.

Perlès C. 1980. Économie de la matière première et économie du débitage: deux exemples grecs. Préhistoire et technologie lithique, Cahiers no. 1 de l'URA 28, Centre national de la recherche scientifique. Paris: 37-41.
1990. L'outillage de pierre taillée néolithique en Grèce: approvisionnement et exploitation des matières premières. Bulletin de Correspondance Hellénique 114(1): $1-42$.

1991. Économie des matières premières et économie du débitage: deux conceptions opposées. 25 ans d'études technologiques en préhistoire: Bilan et perspectives. Actes des XI èmes rencontres internationales d'archéologie et d'histoire d'Antibes, Editions APDCA, Juanles-Pins: 35-45.

2001. The Early Neolithic in Greece. Cambridge University Press. Cambridge.

2007. Échanges et technologie: l'exemple du Néolithique. In Evin J. (ed.), Un siècle de construction du discours scientifique en Préhistoire. Volume III. Aux conceptions d'aujourd'hui. Congrès du centenaire de la Société préhistorique française / XXVIe Congrès préhistorique de France, Avignon, 21-25 septembre 2004. Société Préhistorique Française. Paris: 53-62.

2009. Les industries lithiques néolithiques: logiques techniques et logiques sociales. De Méditerranée et d'ailleurs... Mélanges offerts à Jean Guilaine. Archives d'écologie préhistorique: 557-571.

Perrin T. 2009. New perspectives on the Mesolithic/Neolithic transition in northern Italy. In S. McCartan, R. Schulting, G. Warren, and P. Woodman (ed.), Mesolithic Horizons, volume II. Oxbow Books. Oxford: 514-520.

Perrin T., Binder D. 2014. Le Mésolithique à trapèzes et la néolithisation de l'Europe sud-occidentale. In C. Manen, T. Perrin, and J. Guilaine (eds.), La transition néolithique en Méditerranée, ou comment des chasseurs devinrent agriculteurs. Actes du colloque, Muséum de Toulouse, 1415 avril 2011. Éditions Errance/Archives d'Écologie Préhistorique. Arles: 271-281.

Perrin T., Angelin A., and Defranould E. 2017. Liste typologique pour les industries de pierre taillée de la Préhistoire récente européenne, version 2018-02, en ligne. https://hal.archives-ouvertes.fr/hal-01638819

Podrug E. 2013. Neolithic Immovable Finds in the Šibenik Area. Diadora 26/27: 185-212.

Podrug E., McClure S., Perhoč Z., Kačar S., Reed K., and Zavodny E. in press a. Rašinovac kod Ždrapnja (Sjeverna Dalmacija) - nalazište ranog neolitika. Archaeologia Adriatica.

Podrug E. and 14 co-authors. in press b. Krivače - rezultati arheološkog iskopavanja srednjeneolitičkog naselja i geološkog istraživanja paleojezera u Bribirsko-ostrovič- 
kom polju (sjeverna Dalmacija). Obavijesti Hrvatskog Arheološkog Društva. Hrvatsko arheološko društvo. Zagreb.

Podrug E., Kačar S. in press. Lokalitet Konjevrate-Groblje. Hrvatski Arheološki Godišnjak.

Radina F. 2007. L'insediamento preistorico al Pulo di Molfetta. In F. Radina (ed.), Natura, Archeologia e Storia del Pulo di Molfetta. Bari.

Radović S. 2011. Ekonomija prvih stočara na istočnom Jadranu: značenje lova i stočarstva u prehrani neolitičkih ljudi. Unpublished PhD dissertation. University of Zagreb. Zagreb.

Reed K. 2015. From the Field to the Hearth: Plant Remains from Neolithic Croatia (ca. 6000-4000 cal BC). Vegetation History and Archaeobotany 24(5): 601-619.

Reimer P. and 25 co-authors 2013. IntCal13 and Marine 13 Radiocarbon Age Calibration Curves 0-50,000 Years cal BP. Radiocarbon 55(4): 1869-1887.

https://doi.org/10.2458/azu_js_rc.55.16947

Reingruber A. 2011. Early Neolithic settlement patterns and exchange networks in the Aegean. Documenta Praehistorica 38: 291-305. https://doi.org/10.4312/dp.38.23

Renfrew C. 1984. Approach to Social Archaeology. Edinburge University Press. Edinburgh.

Soressi M., Geneste J.-M. 2011. The History and Efficacy of the Chaîne Opératoire Approach to Lithic Analysis: Studying Techniques to Reveal Past Societies in an Evolutionary Perspective. In G. B. Tostevin (ed.), Reduction Sequence, Chaîne Opératoire and Other Methods: The Epistemologies of Different Approaches to Lithic Analysis. PaleoAnthropology 2011. Special Issue: 334-350. http://doi.org/10.4207/PA.2011.ART63

Surić M. 2006. Promjene u okolišu tijekom mlađeg pleistocena i holocena - zapisi iz morem potopljenih siga istočnog Jadrana. Unpublished $\mathrm{PhD}$ dissertation. University of Zagreb. Zagreb.

Starnini E., Biagi P., and Mazzucco N. 2018. The beginning of the Neolithic in the Po Plain (northern Italy): Problems and perspectives. Quaternary International 470: 301-317. https://doi.org/10.1016/j.quaint.2017.05.059

Šarić J. 2014. Artefakti od okresanog kamena u starijem i srednjem neolitu na tlu Srbije. Arheološki Institut. Beograd.

Šošić-Klindžić R. 2011. The supply system of siliceous rocks between the Drava, Sava and Danube rivers during the Starčevo culture. Documenta Praehistorica 38: 345356. https://doi.org/10.4312/dp.38.27

Šošić R., Karavanić I. 2004. Cijepani litički materijal s prapovijesnog nalazišta Slavča, Nova Gradiška. Vjesnik Arheološkog muzeja u Zagrebu 37(1): 17-41.

Šošić Klindžić R., and 13 co-authors. 2015. Late Upper Paleolithic, Early Mesolithic and Early Neolithic from the Cave Site Zemunica near Bisko (Dalmatia, Croatia). Eurasian Prehistory 12(1-2): 3-46.

Tarantini M., Galiberti A. 2011. Le miniere di selce del Gargano, VI-III millennio a.C. Alle origini della storia mineraria europea. Rassegna di Archeologia - Preistoria e Protostoria 24A. All'Insegna del'Giglio. Firenze.

Tarantini M., Eramo G., Monno A., and Muntoni I. M. 2016. The Gargano Promontory Flint. Mining Practices and Archaeometric Characterisation. In A. Tomasso, D. Binder, G. Martino, G. Porraz, P. Simon, and N. Naudinot (eds.), Ressources lithiques, productions et transferts entre Alpes et Méditerranée. Actes de la journée de la Société préhistorique française de Nice, 28-29 mars 2013, Séances de la Société préhistorique française 5 . Société préhistorique Française. Paris: 257-275.

Turk I. 2004. Viktorjev Spodmol in Mala Triglavca. Prispevki k poznavanju mezolitskega obdobja v Sloveniji Viktorjev spodmol and Mala Triglavca. Contributions to understanding the Mesolithic period in Slovenia. Opera Instituti Archaeologici Sloveniae 9. Inštitut za arheologijo ZRC SAZU. Ljubljana.

Tykot R. H. 2014. Obsidian use and trade in the Adriatic. In P. Visentini, E. Podrug (eds.), Adriatico senza confini. Via di comunicazione e crocevia di popoli nel 6000 a.C./The Adriatic, a sea without borders: communication routes of populations in 6000 BC. Civici Musei di Udine. Museo Friulano di Storia Naturale: 171-181.

Vujević D., Perhoč Z., and Ivančić T. 2017. Micro-Mousterian in Northern Dalmatia. Quaternary International 450: 50-67. http://dx.doi.org/10.1016/j.quaint.2016.11.019

Vukosavljević N., Perhoč Z., and Altherr R. 2014. Prijelaz iz pleistocena u holocen u pećini Vlakno na Dugom otoku (Dalmacija, Hrvatska) - litička perspektiva / PleistoceneHolocene transition in the Vlakno Cave on the island of Dugi otok (Dalmatia, Croatia) - lithic perspective. Prilozi instituta za arheologiju u Zagrebu 31: 5-72.

Vukosavljević N., Perhoč Z. 2017. Lithic raw material procurement of the Late Epigravettian hunter-gatherers from Kopačina Cave (island of Brač, Dalmatia, Croatia). Quaternary International 450: 164-185.

https://doi.org/10.1016/j.quaint.2016.09.017 


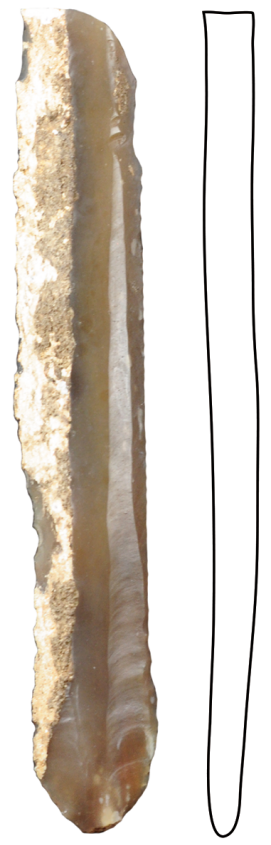

1
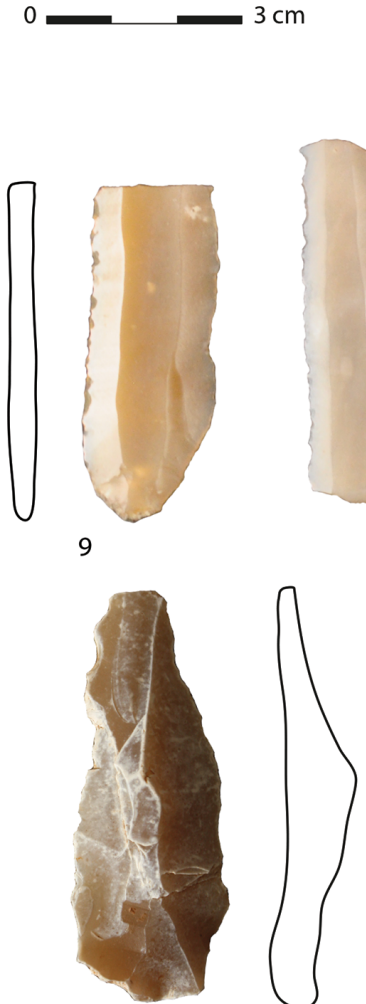

14
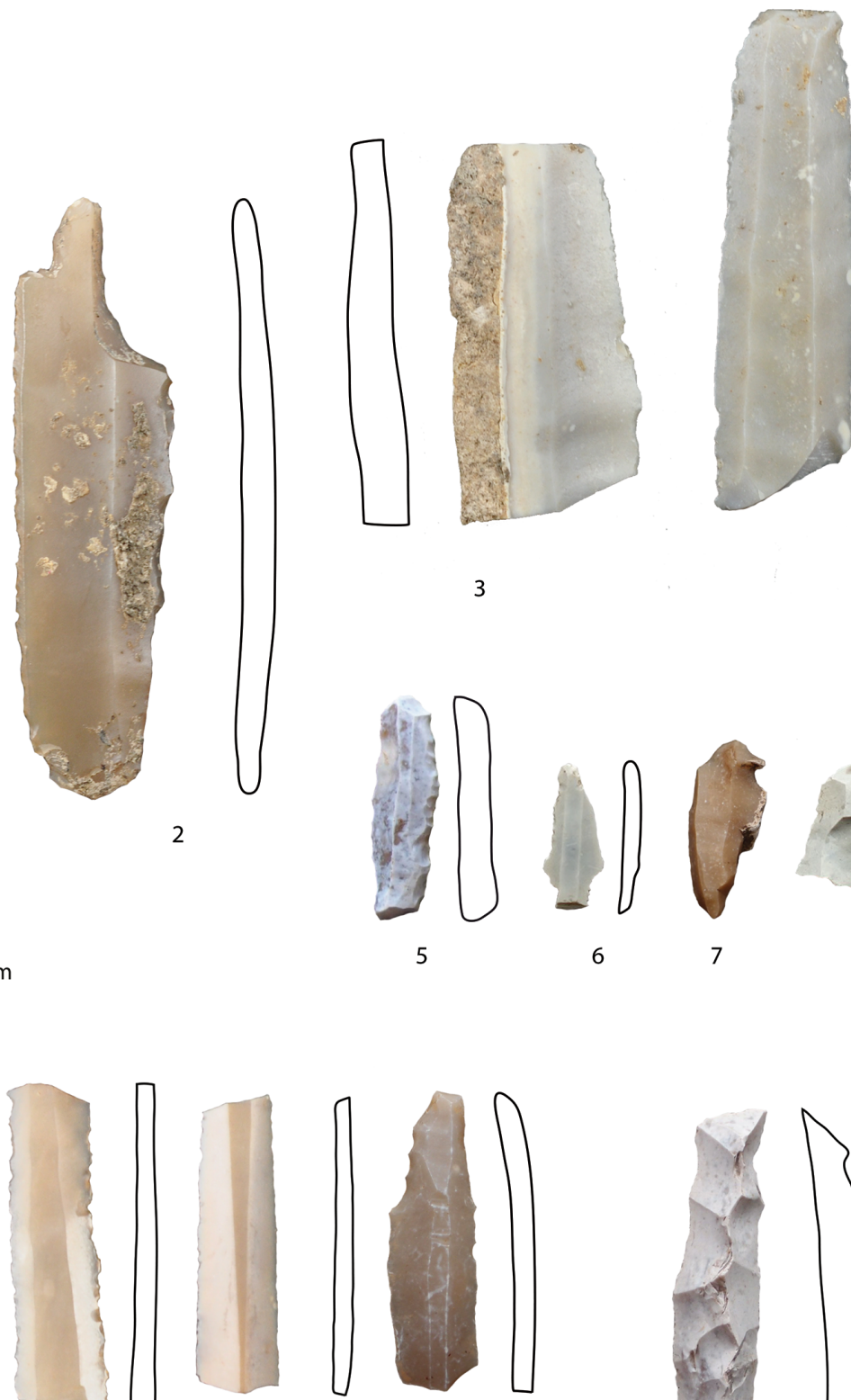

12

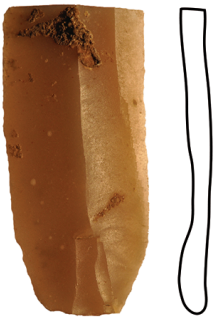

15

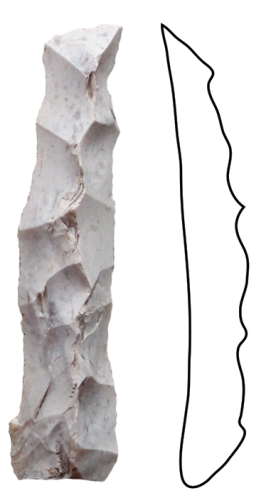

13

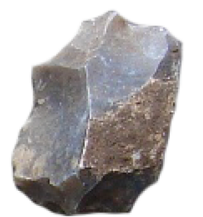

16

Pl. 1. Early Neolithic lithic assemblages from Northern Dalmatia. 1-4, 9-11,15 Crno Vrilo: lever pressured blades (1-2 and possibly 3-4) and pressure flaked blades, mode 4 (9-12, 15); 5, 6, 8 Rašinovac blades and core renewal flake (core tablet); 7, 13 Vrbica: core renewal flake (core fragment) and crested blade; 12, 14 Konjevrate: blade and crested blade; 16. Vrbica flake core. $N .1,2,5$ and 12 are retouched (1 notched bladed, 2 burin, 5 blade with abrupt retouch, and 12 borer) and 9-11 are glossy. All artefacts are on presumed Gargano flint. 

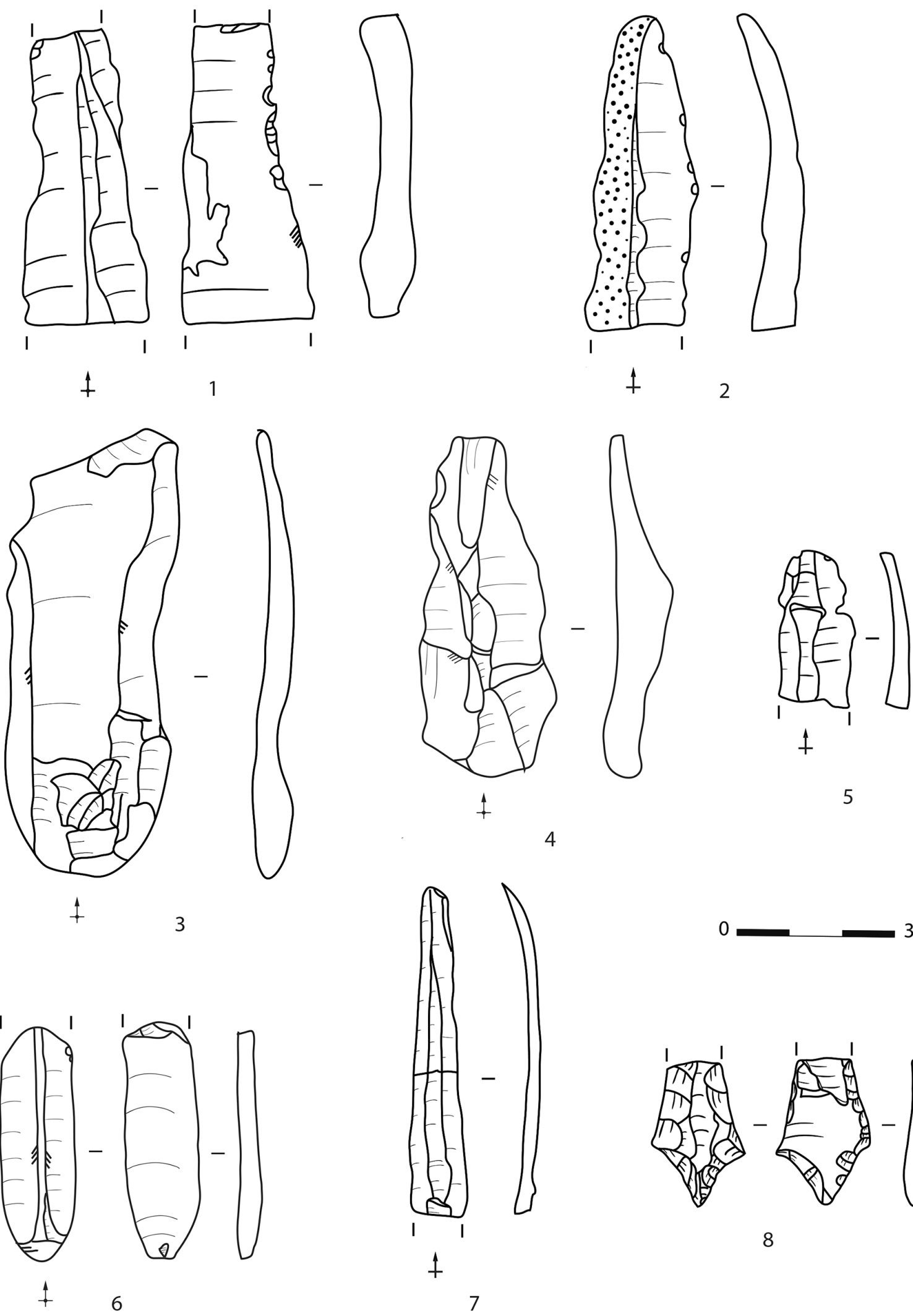

$3 \mathrm{~cm}$
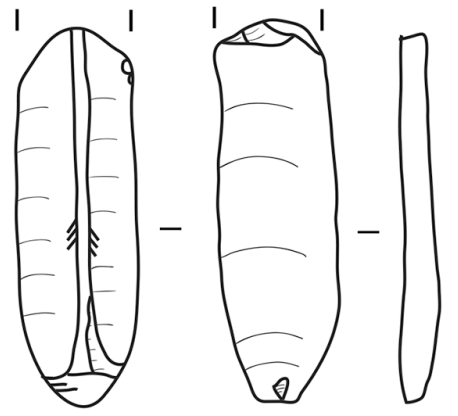

1

6

Pl. 2. Early Neolithic blades from Northern Dalmatia. Blades testifying to core renewal $(1,3,4,5)$ and cortical blade (2); 1- 4 (1, 2 Vrbica; 3 Tinj; 4 Konjevrate) are probably made by indirect percussion and 5 (Rašinovac) probably by direct percussion. Pressure flaked blades: 6 Konjevrate and 7 Polje Niže Vrcelja. Pressure flaked bifacial point from Vrbica (8). All artefacts are on presumed Gargano flint. 